\title{
Diagnostics of the Tropical Tropopause Layer from in-situ observations and CCM data
}

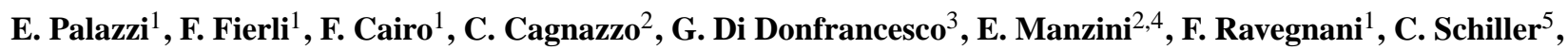 \\ F. D'Amato ${ }^{6}$, and C. M. Volk ${ }^{7, *}$ \\ ${ }^{1}$ ISAC-Institute for Atmospheric Sciences and Climate, National Research Council, Italy \\ ${ }^{2}$ CMCC-Centro Euro-Mediterraneo per i Cambiamenti Climatici, Italy \\ ${ }^{3}$ ENEA-Ente Nuove Tecnologie Energia e Ambiente, Rome, Italy \\ ${ }^{4}$ INGV-Istituto Nazionale di Geofisica e Vulcanologia, Italy \\ ${ }^{5}$ FZJ, Forschungzentrum Julich, GMBH, Germany \\ ${ }^{6}$ INOA-CNR, Istituto Nazionale di Ottica Applicata, Italy \\ ${ }^{7}$ J. W. Goethe University, Frankfurt, Germany \\ *now at: Department of Physics, University of Wuppertal, Germany
}

Received: 24 April 2009 - Published in Atmos. Chem. Phys. Discuss.: 12 May 2009

Revised: 19 November 2009 - Accepted: 30 November 2009 - Published: 15 December 2009

\begin{abstract}
A suite of diagnostics is applied to in-situ aircraft measurements and one Chemistry-Climate Model (CCM) data to characterize the vertical structure of the Tropical Tropopause Layer (TTL). The diagnostics are based on vertical tracer profiles and relative vertical tracer gradients, using tropopause-referenced coordinates, and tracer-tracer relationships in the tropical Upper Troposphere/Lower Stratosphere (UT/LS).

Observations were obtained during four tropical campaigns performed from 1999 to 2006 with the research aircraft Geophysica and have been compared to the output of the ECHAM5/MESSy CCM. The model vertical resolution in the TTL $(\sim 500 \mathrm{~m})$ allows for appropriate comparison with high-resolution aircraft observations and the diagnostics used highlight common TTL features between the model and the observational data.

The analysis of the vertical profiles of water vapour, ozone, and nitrous oxide, in both the observations and the model, shows that concentration mixing ratios exhibit a strong gradient change across the tropical tropopause, due to the role of this latter as a transport barrier and that transition between the tropospheric and stratospheric regimes occurs within a finite layer. The use of relative vertical ozone and carbon monoxide gradients, in addition to the vertical profiles, helps to highlight the region where this transition occurs and al-
\end{abstract}

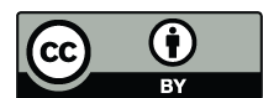

Correspondence to: E. Palazzi (e.palazzi@isac.cnr.it) lows to give an estimate of its thickness. The analysis of the $\mathrm{CO}-\mathrm{O}_{3}$ and $\mathrm{H}_{2} \mathrm{O}-\mathrm{O}_{3}$ scatter plots and of the Probability Distribution Function (PDF) of the $\mathrm{H}_{2} \mathrm{O}_{-} \mathrm{O}_{3}$ pair completes this picture as it allows to better distinguish tropospheric and stratospheric regimes that can be identified by their different chemical composition.

The joint analysis and comparison of observed and modelled data allows to state that the model can represent the background TTL structure and its seasonal variability rather accurately. The model estimate of the thickness of the interface region between tropospheric and stratospheric regimes agrees well with average values inferred from observations. On the other hand, the measurements can be influenced by regional scale variability, local transport processes as well as deep convection, that can not be captured by the model.

\section{Introduction}

The extreme dryness of the stratosphere was used by Brewer (1949) to deduce that air entered the stratosphere primarily in the tropics, within the so called Tropical Tropopause Layer (TTL) (Highwood and Hoskins, 1998; Folkins et al., 1999; Gettelman and Forster, 2002). This transition layer has properties both of the troposphere and the stratosphere and, in the tropics, may extend over several kilometers vertically encompassing the tropopause. The TTL is of interest not only because of being the interface between two very different dynamical regimes but also because it acts as a gate to

Published by Copernicus Publications on behalf of the European Geosciences Union. 
the stratosphere for atmospheric tracers such as water vapour and other short lived substances, which both play an important role for stratospheric chemistry and climate (Holton et al., 1995).

The ascending branch of the Brewer-Dobson circulation transports mass upward in the tropics from the upper troposphere driving the vertical stratospheric motion. The stratospheric Brewer-Dobson circulation is also key to the "atmospheric tape recorder" signals in water vapour and other compounds like $\mathrm{CO}_{2}$ (Andrews et al., 1999; Park et al., 2007) and CO (Schoeberl et al., 2006). The tape recorder is the name given to the slow upward movement of trace gases into the tropical stratosphere and apparently all that is required for a tape recorder is a trace gas that varies in concentration with time near the tropical tropopause. The tape recorder in water vapour, in particular, was observed by Mote et al. (1996) using measurements from the satelliteborne Microwave Limb Sounder (MLS) and Halogen Occultation Experiment (HALOE) instruments, showing that air transported upward retains a memory for tropical tropopause conditions for at least 18 months, as it is advected upward by the large scale circulation. The seasonal variation of water vapour in the tropical lower stratosphere, in fact, is clearly tied to the seasonality in tropical tropopause temperatures, which are correlated with the seasonal variability of "freeze-drying" process in the upper troposphere and tropical tropopause region (Randel et al., 2001). The freeze-drying mechanism is responsible for the low water vapour values in the lower stratosphere, since air passing through the tropical tropopause has its water vapour mixing ratio reduced to the ice saturation value at or near the tropopause.

The processes that contribute to the unique properties of the TTL, identified as the zone where the properties of both troposphere and stratosphere can be observed, are subject of long debates and studies, focusing on the use of both observational and model data (Fueglistaler et al., 2009). In-situ observations in the Upper Troposphere/Lower Stratosphere (UT/LS) are unique in terms of accuracy, sensitivity, and resolution but they are sparse for season and regions. The study of the tropical UT/LS has been carried out in the frame of several observational activities since the 1980s. In the frame of the Stratosphere-Troposphere Exchange Project Tropical Experiment (STEP Tropical) a measurement campaign was conducted to investigate stratosphere-troposphere exchange and dehydration processes in that region and season with the coldest average tropopause temperatures, the tropical western Pacific and northern Australia during the winter monsoon (January-February) of 1987 (Russell et al., 1993). Aircraft measurements of water vapour were also made within the Central Equatorial Pacific Experiment (CEPEX) performed during March and April 1993 (Weinstock et al., 1995). They yielded a picture of a seasonal water vapour cycle consistent with the variation of the average tropical tropopause temperature and provided an annually averaged mixing ratio of water in air entering the tropical stratosphere of about
4.45 ppmv. Satellite observations, on the other hand, can be used to extend field campaign data, as well as employing data from aircraft to validate satellites. Tropical aerosol composition and size measurements in the TTL, for example, were performed during the Pre-Aura Validation Experiment (Pre-AVE) in January-February 2004 (Froyd et al., 2009). Satellite data provide a global picture and context for more detailed in-situ aircraft observations, and guarantee an extensive geographical coverage and measurement continuity, though their typical vertical resolution only recently started to allow for evaluations in the UT/LS region; see for instance the work presented in Hegglin et al. (2008), where $\mathrm{CO}, \mathrm{O}_{3}$, and $\mathrm{H}_{2} \mathrm{O}$ data in the UT/LS measured by the Atmospheric Chemistry Experiment Fourier Transform Spectrometer (ACE-FTS) on Canada's SCISAT-1 satellite are validated using aircraft and ozonesonde measurements.

In-situ and satellite observations are a crucial complement to global modeling efforts and can be exploited to correctly estimate the capability of current Chemical Circulation Models (CCMs) to reproduce the structure of the TTL. In a recent study Gettelman and Birner (2007) have discussed the capability of two CCMs in describing the key structural features of the TTL including the mean state and the variability of temperature, ozone, clouds, and thermal structure. They concluded that the TTL features must be largely regulated by the large scale processes, since the TTL structure seemed not altered by sub-grid scale processes such as convection. Another recent study by Kremser et al. (2009) focuses on the representation in two CCMs, differing in their horizontal and vertical resolutions, of the processes that determine the flux of water vapour through the TTL and their importance for stratospheric water vapour fields. The water vapour mixing ratios and geographical distribution of dehydration points provided by the two CCMs are compared to ERA-40 reanalysis data, resulting in different regions of water vapour entry into the stratosphere and water vapour concentrations in the lower stratosphere simulated by the CCMs. Gettelman et al. (2009) present a broad analysis of the TTL in thirteen different CCMs and discuss simulations for 1960-2005 and 19802100. Results indicate that the CCMs can in general reproduce the basic structure of the TTL and its variability. Nevertheless, several inconsistencies are found and one of most critical points seems to be the simulation of TTL ozone, that actually varies tremendously in the CCMs, and also seems to be correlated with the absolute value of tropopause temperature.

The validation of CCMs with observational data sets from in-situ or remote sensing measurements can further be improved using diagnostics that are able to reveal peculiar features in the tropical UT/LS tracers distribution. These diagnostics are key indicators of whether the contributions of dynamics and chemistry to the tropical tropopause region are correctly represented in the models, and have been used by several authors to perform comparisons between models and measurements, e.g. in the extra-tropics. For instance, Pan 
et al. (2007) showed that strong gradients in tracer distributions and mixing across the extra-tropical tropopause can be highlighted when moving from geometric altitude coordinates into tropopause-referenced coordinates or in tracertracer space.

In this paper, we perform a joint analysis of insitu high-resolution measurements performed on-board the research aircraft Geophysica during four tropical campaigns - APE-THESEO (February-March 1999, Seychelles), TROCCINOX (January-February 2005, Brazil), SCOUT-Darwin (November-December 2005, Australia), and SCOUT-AMMA (August 2006, West-Africa) - and the ECHAM5/MESSy CCM. The aircraft measurements include observation of a wide number of chemical species over the whole TTL depth, in different regions and seasons. Here $\mathrm{O}_{3}, \mathrm{~N}_{2} \mathrm{O}$, water vapour, and $\mathrm{CO}$ are chosen in order to characterize the TTL vertical variability. The diagnostics used, which have been successfully applied in the extra-tropical tropopause region (Pan et al., 2007; Hegglin et al., 2009), are based on the analysis of vertical profiles of water vapour, ozone, and nitrous oxide and of relative vertical ozone and $\mathrm{CO}$ gradients, in a tropopause-referenced coordinate, and on $\mathrm{CO}-\mathrm{O}_{3}$ and $\mathrm{H}_{2} \mathrm{O}-\mathrm{O}_{3}$ correlations. They are applied to observational and model data, encouraging in this way a comparison between the model and the observations, with a threefold objective:

- highlight some features of the TTL vertical structure and its regional/temporal variability,

- evaluate the capability of the model in reproducing the observed TTL vertical structure and its variability,

- assess whether observations from particular regions on a monthly timescale can be representative of the fine scale mean structure of the TTL.

The paper will be arranged as follows. Section 2 presents the observations and the main characteristics of the model run. Section 3 describes the methodology used to compare the observations and the ECHAM5/MESSy data, and the diagnostics used (tropopause coordinates, tracer-tracer correlations, and relative vertical tracer gradients) are described. Section 4 provides the comparison of the measured and modelled vertical tracers profiles and relative vertical gradients around the tropical tropopause. In Sect. 5, we focus on the analysis of $\mathrm{CO}-\mathrm{O}_{3}$ and $\mathrm{H}_{2} \mathrm{O}-\mathrm{O}_{3}$ correlations in the TTL, for both the model and the observations. Section 6 gives the main conclusions of this work.

\section{Description of the campaigns and the model data}

\subsection{The measurement campaigns}

The experimental data presented in this paper were obtained during four tropical measurement campaigns performed at different times and locations with the high-altitude
M55 Geophysica aircraft. APE-THESEO (Airborne Platform for Earth observation - contribution to the Third European Stratospheric Experiment on Ozone) was performed from 15 February to 15 March 1999, in the Seychelles (Stefanutti et al., 2004). TROCCINOX (TROpical Convection, Cirrus and Nitrogen Oxides Experiment) was carried out in January and February 2005 in Brazil (ACP special issue "TROCCINOX-Tropical convection and its impact on the troposphere and lower stratosphere"). SCOUT-Darwin (Stratospheric-Climate Links with Emphasis on the Upper Troposphere and Lower Stratosphere) took place in Australia, in November-December 2005 (Vaughan et al., 2008). SCOUT-AMMA (African Monsoon Multidisciplinary Analyses) was performed in August 2006 in Burkina Faso, West Africa (Law et al., in preparation, 2009). The red boxes in Fig. 1 indicate the regions where the aircraft flights planned in the frame of the four campaigns took place (the measurements taken during the transfer flights have not been included in our analysis).

The scientific objectives of the campaigns were to study chemical processes and transport into the TTL and across the tropopause. In particular, all the campaigns focused on the analysis of such processes in deep convective systems, such as the continental convection over Brazil during TROCCINOX (Chaboureau et al., 2006), the isolated "Hector" storms over the Northern Australian archipelago during SCOUTDarwin (Brunner et al., 2009) and the African monsoon during SCOUT-AMMA. Consequently, all the campaigns included a fraction of flights useful to study the impact of convection on the mean chemical structure of the upper troposphere. Therefore, a bias toward convectively influenced observations can be expected, markedly in the SCOUT-Darwin campaign and to a lesser extent in the SCOUT-AMMA and TROCCINOX campaigns. Direct convection events can for example alter the water budget at the tropical tropopause, leading to a moistening of the lower stratosphere at least locally (Chaboureau et al., 2006; Corti et al., 2008). APETHESEO measurements, which took place during a relatively quiescent period, can be considered to be the dataset least influenced by convection. In our analysis, no filters have been applied on the observations to remove the impact of the small-scale transport processes related to convective activity.

Table 1 lists the instruments used on board the aircraft Geophysica for the measurement of the atmospheric compounds considered in our study, along with their accuracy and precision. Table 2 specifies the latitudinal and longitudinal domain and the temporal collocation of the measurement campaigns analyzed in this study.

\subsection{Numerical model}

The atmospheric chemistry general circulation model used in our study consists of ECHAM5 (Roeckner et al., 2003, 2006) coupled with the Modular Earth Submodel System, MESSy. This model includes a comprehensive 


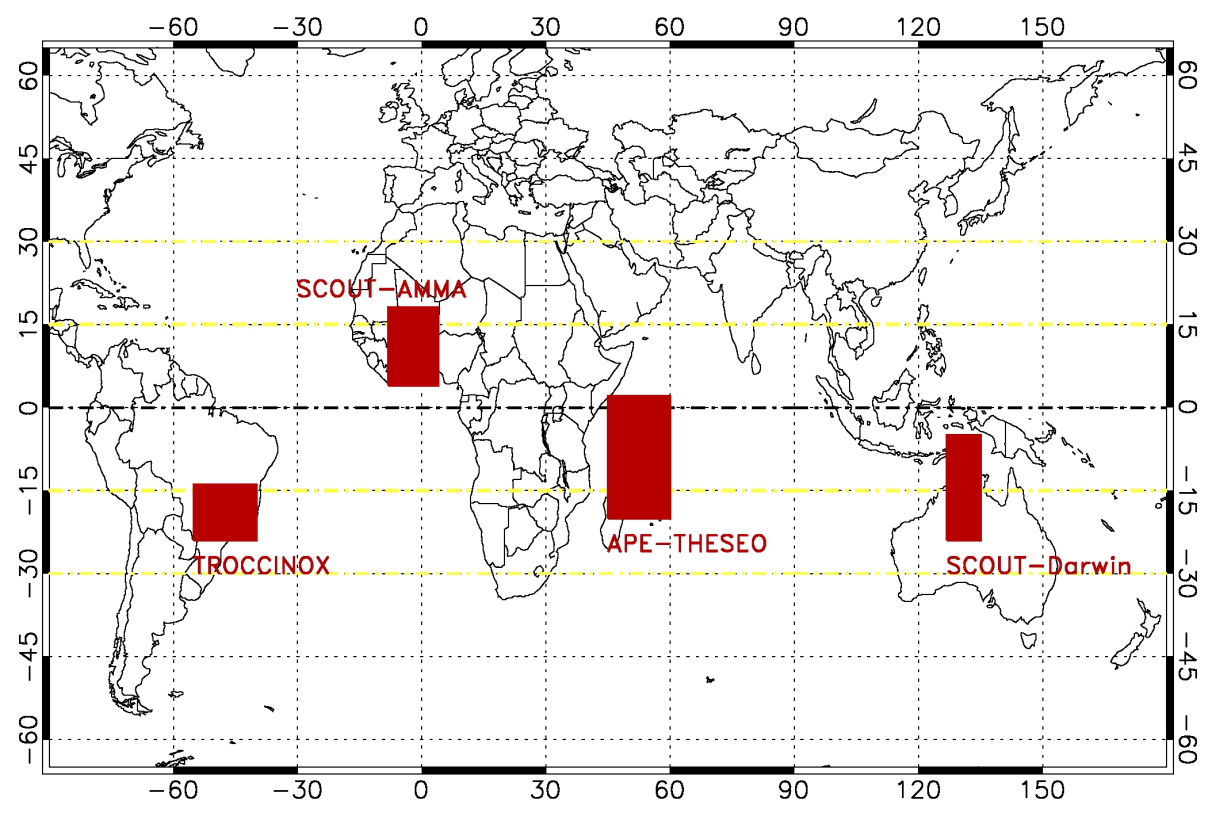

Fig. 1. Geographic location of the four measurement campaigns considered in this study. The red boxes indicate the areas where most flights were carried out (the transfer flights are not included in our analysis) and comparison between the observations and the model data has actually been performed.

Table 1. List and principal characteristics of the instruments onboard the Geophysica aircraft during APE-THESEO, TROCCINOX, SCOUTDarwin and SCOUT-AMMA campaigns. In this study, ozone data come from FOZAN instrument for all the campaigns except than APETHESEO, for which data from ECOC instrument have been considered. CO mixing ratios were not measured during APE-THESEO.

\begin{tabular}{|c|c|c|c|c|c|}
\hline Instrument & $\begin{array}{l}\text { Measured } \\
\text { parameter }\end{array}$ & Technique & $\begin{array}{l}\text { Averaging } \\
\text { time }\end{array}$ & Accuracy & Precision \\
\hline $\begin{array}{l}\text { FOZAN } \\
\text { Yushkov et al. (1999) }\end{array}$ & $\mathrm{O}_{3}$ & $\begin{array}{l}\text { Dye } \\
\text { chemi- } \\
\text { luminescence }\end{array}$ & $1 \mathrm{~s}$ & $\begin{array}{l}0.01 \\
\text { ppmv }\end{array}$ & $8 \%$ \\
\hline $\begin{array}{l}\text { ECOC } \\
\text { Kyrö et al. (2000) }\end{array}$ & $\mathrm{O}_{3}$ & $\mathrm{ECC}$ & $5 \mathrm{~s}$ & $5 \%$ & $2 \%$ \\
\hline $\begin{array}{l}\text { FISH } \\
\text { Zöger et al. (1999) }\end{array}$ & $\mathrm{H}_{2} \mathrm{O}$ (total) & $\begin{array}{l}\text { Lyman- } \alpha \\
\text { photo-fragment } \\
\text { flourescence }\end{array}$ & $1 \mathrm{~s}$ & $6 \%$ & $\begin{array}{l}0.2 \\
\text { ppmv }\end{array}$ \\
\hline $\begin{array}{l}\text { HAGAR } \\
\text { Volk et al. (2000) }\end{array}$ & $\mathrm{N}_{2} \mathrm{O}$ & GC-ECG & $70 \mathrm{~s}$ & $2 \%$ & $1 \%$ \\
\hline $\begin{array}{l}\text { COLD } \\
\text { Viciani et al. (2008) }\end{array}$ & $\mathrm{CO}$ & TDL & $4 \mathrm{~s}$ & $9 \%$ & $1 \%$ \\
\hline
\end{tabular}

representation of clouds, radiation, multiphase chemistry and emission-deposition processes (Jöckel et al., 2006). The model computes the atmospheric dynamics up to wavenumber 42 using a triangular truncation (T42), which allows to predict the prognostic variables every $15 \mathrm{~min}$. The associated quadratic Gaussian grid, where physical and chemical parameterizations are calculated, is of approximately $2.8^{\circ}$ in latitude and longitude (Roeckner et al., 2006). The vertical grid resolves the atmosphere with 90 vertical layers reaching up to $0.01 \mathrm{hPa}(\sim 80 \mathrm{~km}$ altitude). The mean layer thickness in the lower and middle stratosphere is about $700 \mathrm{~m}$, which allows for a resolution high enough to internally generate the quasi-biennial oscillation (QBO), as shown by Giorgetta et al. (2006). The vertical resolution in the tropopause region is higher, about $500 \mathrm{~m} \mathrm{(6-10} \mathrm{hPa).}$

Further general description of the model setup can be found in Jöckel et al. (2006); the radiation scheme is accurately described in Cagnazzo et al. (2007) and information about coupling of ECHAM5 with MESSy can be found in Jöckel et al. (2005) (see also http://www.messy-interface. org/). 

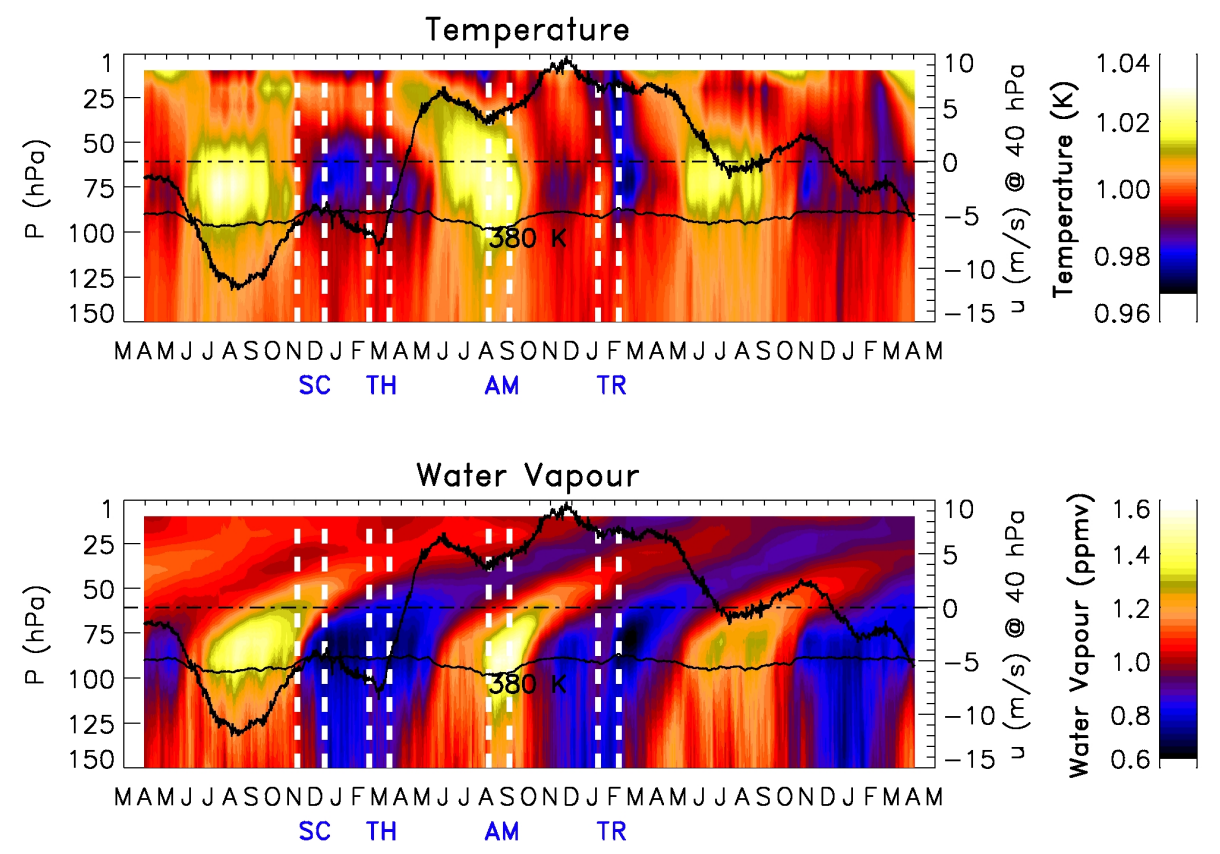

Fig. 2. Variation of $15^{\circ} \mathrm{S}$ and $15^{\circ} \mathrm{N}$ mean ECHAM5/MESSy temperature and water vapour after dividing by the mean value at each levels. Each panel also shows the isentropic surface at $\theta=380 \mathrm{~K}$ (here used as a proxy of the tropical tropopause) and the zonal mean zonal wind at $40 \mathrm{hPa}$. The dashed vertical lines mark the temporal domains of the four measurement campaigns $(\mathrm{SC}=\mathrm{SCOUT}-\mathrm{Darwin}, \mathrm{TH}=\mathrm{APE}-\mathrm{THESEO}$, AM=SCOUT-AMMA, TR=TROCCINOX) and locate them within the three model years.

The cloud microphysics scheme implemented in the CCM is described in Lohmann and Roeckner (1996) and includes phase changes between the water components (condensation/evaporation, deposition/sublimation, and freezing/melting) and precipitation processes (autoconversion, accretion, and aggregation). Moreover, the evaporation of rain and the melting of snow are considered as well as the sedimentation of cloud ice.

The simulation presented here is a three year run, forced with climatological sea surface temperatures (SSTs), so the effect of El Niño or La Niña are not included. The model is not forced through nudging on dynamical variables towards atmospheric analyses and hence it performs a free run both in the troposphere and in the stratosphere.

For the representation of natural and anthropogenic emissions and the boundary conditions for the chemical species considered in this study, we refer to the detailed description by Kerkweg et al. (2006). We have used 3-D fields of the chemical and dynamical variables taken at 12:00 UTC every day, in the height range between $300 \mathrm{hPa}$ and $10 \mathrm{hPa}$.

Figure 2 shows the variation of the model monthly mean temperature (top) and water vapour (bottom), averaged between $15^{\circ} \mathrm{S}$ and $15^{\circ} \mathrm{N}$. The monthly means are divided by the time mean value at each level. The isentropic surface at $\theta=380 \mathrm{~K}$ (here used as a proxy of the tropical tropopause) and the zonal mean zonal wind at $40 \mathrm{hPa}$ are also shown, as well as the time periods chosen to perform the comparison with the observations from the four campaigns. Model months match closely with the observational temporal coverage, while model years are selected so that model and aircraft data lie in the same QBO phase. The last column of Table 2 shows the number of model grid points within the geographical box defined for each measurement campaign (see Sect. 2.1).

Figure 2 clearly shows the presence of a tape recorder signal in the ECHAM5/MESSy water vapour. $\mathrm{H}_{2} \mathrm{O}$ follows an annual cycle between about 150 and $100 \mathrm{hPa}$ that propagates upward in the whole domain under analysis. Minima of $\mathrm{H}_{2} \mathrm{O}$ at the tropopause are found in the $\mathrm{NH}$ winter (corresponding to APE-THESEO, TROCCINOX, SCOUT-Darwin temporal and spatial domains) while the maxima occur in the NH summer (SCOUT-AMMA), when the temperatures at the tropopause are lowest and highest, respectively. In Sect. 4.2 it will be shown that this seasonal variability in water vapour is seen in the observational data as well, and agrees with the one reproduced by the model.

The simulated $\mathrm{H}_{2} \mathrm{O}$ tape recorder can be compared to the MLS water vapour shown in the paper by Liu et al. (2007) (Fig. 1a). At $100 \mathrm{hPa}$ the greater (lower) than one water vapour values roughly span from June to November (November to June) for both MLS and ECHAM5/MESSy. At $70 \mathrm{hPa}$ the agreement between MLS and the model is still consistent, with a one-month phase shift. At $50 \mathrm{hPa}$, on the other hand, the MLS water vapour greater (lower) than one values span from September to May (May to September), while for ECHAM5/MESSy from September to March 
Table 2. Location and time period of the four aircraft campaigns. The number of model grid points within the latitude-longitude box for each campaign is indicated.

\begin{tabular}{|c|c|c|c|c|c|}
\hline Campaign & Time & Region & Lat-Lon $\left(^{\circ}\right)$ & QBO & $\begin{array}{l}\text { Model } \\
\text { grid } \\
\text { points }\end{array}$ \\
\hline APE-THESEO & $\begin{array}{l}\text { February- } \\
\text { March } 1999\end{array}$ & Seychelles & $\begin{array}{l}\text { lat:[}[-20,2] \\
\text { lon:[45,60] }\end{array}$ & $\begin{array}{l}\text { beginning of } \\
\text { positive QBO } \\
\text { (westerly winds) }\end{array}$ & 48 \\
\hline TROCCINOX & $\begin{array}{l}\text { January- } \\
\text { February } 2005\end{array}$ & Brazil & $\begin{array}{l}\text { lat: }[-24,-14] \\
\text { lon:[-55,-40] }\end{array}$ & positive QBO & 20 \\
\hline SCOUT-Darwin & $\begin{array}{l}\text { November- } \\
\text { December } 2005\end{array}$ & Australia & $\begin{array}{l}\text { lat:[-24,-5] } \\
\text { lon:[127,135] }\end{array}$ & negative QBO & 21 \\
\hline SCOUT-AMMA & August 2006 & West-Africa & $\begin{array}{l}\text { lat: }[-14,28] \\
\text { lon:[-8,4] }\end{array}$ & positive QBO & 60 \\
\hline
\end{tabular}

(March to September). At higher levels $(30 \mathrm{hPa})$, the MLS water vapour greater than one values span from about February to October, while for ECHAM5/MESSy approximately from January to July. The comparison between the MLS and ECHAM5/MESSy water vapour tape recorder gives an overall good agreement in the lowermost stratosphere (pressure $<70 \mathrm{hPa}$ ), while a phase shift of approximately two months appears at $50 \mathrm{hPa}$ and $30 \mathrm{hPa}$. The estimated phase shift in the vertical propagation of water vapour suggests a too fast model vertical advection, in agreement with what reported in the study by Eyring et al. (2006), that summarizes the results of simulations from thirteen CCMs designed to represent the stratosphere. What appears from the comparison of the water vapour tape recorder between the CCMs and HALOE measurements (Fig. $9 \mathrm{~b}$ of Eyring et al., 2006) is a phase lag spanning from two to five months in the models (in a range of altitudes comparable to that considered in our evaluation), consistent with ECHAM5/Messy phase lag respect to MLS. The difference in the speed of propagation of the water vapour signal between MLS (Liu et al., 2007) and ECHAM5/Messy (Fig. 2) is therefore linked to the model transport and dynamics that, if not correctly represented, may affect model solutions.

The ECHAM5/MESSy water vapour tape recorder is also in agreement with the results obtained by Lelieveld et al. (2007), who compared the ECHAM5/MESSy1 model with realistic tropospheric nudging for the period 1996-2005 to the HALOE water vapour observations.

\section{Methodology}

\subsection{Diagnostic methods}

The exchange of chemical constituents between the upper troposphere and the lower stratosphere takes place across the tropopause, which is marked by a transition in the values of atmospheric concentration of compounds such as water vapour, ozone, and various nitrogen oxides. However, observations of temperature, winds, and atmospheric trace gases suggest that the transition from troposphere to stratosphere occurs in a layer, rather than at a sharp tropopause. In the tropics this layer is known as the Tropical Tropopause Layer (Fueglistaler et al., 2009). The TTL can be qualitatively defined as the region where the tropospheric convection effect remains but no longer dominates the setting of the temperature structure which - as in the stratosphere - is mainly affected by radiative processes (Thuburn and Craig, 2002). However, the TTL is currently not well or consistently defined, leading to various definitions of its vertical boundaries and thickness (Gettelman and Forster, 2002; Highwood and Hoskins, 1998; Sherwood and Dessler, 2001; Folkins et al., 1999; Vömel et al., 2002).

The use of appropriate diagnostic methods helps to highlight the vertical distribution of tracers across the tropopause and the chemical characteristics of the intermediate layer between the tropospheric and stratospheric regimes. Such diagnostics were described and applied to quantify the extratropical transition layer thickness and variability from satellite, in-situ and model data (see Pan et al., 2004; Hoor et al., 2004; Pan et al., 2007; Hegglin et al., 2008; Hegglin et al., 2009). The suite of diagnostics, here applied to the tropical transition layer, is described below.

\subsubsection{Tropopause coordinates}

In this study, a tropopause coordinate (i.e., using vertical profiles of a variable of interest relative to the tropopause height or pressure) is used rather than the geometric altitude or pressure as the vertical coordinate, since it highlights the characteristics of tracer transition across the tropopause and the climatological features of the chemical distribution in the UT/LS, minimizing the effects of day-to-day variability related to meteorological factors (Pan et al., 2007). The tropopause-referenced vertical profiles of chemical tracers are indeed more compact than if they were plotted in 
geometric altitude/pressure or potential temperature coordinates, and reveal the sharp gradient change between tropospheric and stratospheric mixing ratios (Pan et al., 2004; Hoor et al., 2004; Hegglin et al., 2006, and references therein).

In addition, the tropopause coordinate system facilitates the identification and representation in Chemistry-Climate Models of the specific structure of a given tracer across the tropopause and within the TTL, allowing for a direct comparison between model data and measurements and for processoriented validation of CCMs.

By convection of the World Meteorological Organization (WMO), the tropopause is defined as the lowest level at which the temperature lapse rate becomes less than $2 \mathrm{~K} \mathrm{~km}^{-1}$, provided that the average lapse rate between this level and all higher levels within $2 \mathrm{~km}$ does not exceed $2 \mathrm{~K} \mathrm{~km}^{-1}$ (WMO, 1957). This conventional thermal definition of the tropopause has been used throughout the present paper. Nevertheless, it is known that the tropical tropopause corresponds roughly to the isentropic surface $\theta \approx 380 \mathrm{~K}$ (in the annual mean), a definition that emphasizes the quasimaterial behaviour of the tropopause. $\theta=380 \mathrm{~K}$ has been used as a proxy for the tropical tropopause in Sect. 2.2, Fig. 2.

\subsubsection{Vertical tracer gradients}

The use of relative vertical tracer gradients (the ratio between the vertical tracer gradients and the tracer concentrations), plotted in tropopause coordinates, which are equivalent to the vertical gradients of the logarithm of the tracer concentration, is particularly useful to identify the vertical distribution of the layers where tracers characterized by strong gradients across the tropopause show high variability. This approach has been used by Hegglin et al. (2009) to supply a measure of the extra-tropical tropopause transition layer depth and reveal its latitudinal structure using the vertical gradients of $\mathrm{CO}$ and $\mathrm{O}_{3}$ mixing ratios from the limb-viewing Atmospheric Chemistry Experiment-Fourier Transform Spectrometer. Birner (2006), using high-resolution radiosonde data, showed that the dynamical tropopause is characterized by a transition layer with strongly enhanced static stability lying just above the extratropical thermal tropopause, and it was called Tropopause Inversion Layer (TIL). Seasonal and latitudinal variations of the TIL have been investigated by Randel et al. (2007) using GPS occultation data. They showed that the strong gradients in $\mathrm{H}_{2} \mathrm{O}$ and $\mathrm{O}_{3}$ observed across the tropopause may contribute to the temperature inversion just above the tropopause that defines the TIL. Hegglin et al. (2009) investigates the characteristics of and the relation between the Extra-tropical tropopause Transition Layer (ExTL) and the TIL, showing that the vertical $\mathrm{H}_{2} \mathrm{O}$ gradients have a similar pattern as the static stability structure of the TIL.

In this study, the relative vertical gradients of ozone and $\mathrm{CO}$ are utilised. The former is a tracer which represents stratospheric origin and the latter represents tropospheric ori- gin. Both tracers show a decrease away from their source region. The relative vertical gradients of $\mathrm{O}_{3}$ and $\mathrm{CO}$ are analyzed and correlated to the profile of $N^{2}$, to derive the top and bottom bounds of the region where stratospheric and tropospheric tracers are expected to be both present at significant concentrations.

\subsubsection{Tracer-tracer correlations}

To characterize the chemical transition across the tropopause, use can also be done of the theory of relationships between a tropospheric and a stratospheric tracer. Until now, this approach has been widely applied in the extra-tropics (Pan et al., 2007; Hegglin et al., 2009) to derive the extra-tropical tropopause layer depth using $\mathrm{CO}-\mathrm{O}_{3}$ and $\mathrm{H}_{2} \mathrm{O}-\mathrm{O}_{3}$ correlations. The connection between tracer profiles in altitude space and tracer-tracer space in the extra-tropical UT/LS region has been clearly illustrated in Fig. 6 of Pan et al. (2004).

In an atmosphere with ideally no mixing between troposphere and stratosphere (i.e., where the tropopause would act as a perfectly impermeable barrier to vertical transport) the correlation between a tropospheric and a stratospheric tracer would have the typical " $L$ " shape predicted from the theory (Plumb, 2007), with a nearly linear relationship between the tracer mixing ratios for both the tropospheric and stratospheric branches. This shape is likely expected in the tropics, at least for the $\mathrm{H}_{2} \mathrm{O}_{-} \mathrm{O}_{3}$ pair, since cross-tropopause mixing is small and upward motion from the troposphere to the stratosphere is associated with dehydration at the tropopause (Brewer, 1949). Nevertheless, Hegglin et al. (2009) showed that, in the extra-tropics, the correlations between the stratospheric $\mathrm{O}_{3}$ and the tropospheric $\mathrm{CO}$ or $\mathrm{H}_{2} \mathrm{O}$ move from the linearity an exhibit a curvature, which is associated to the importance of mixing and stratosphere-troposphere exchange mechanisms that lead to the erosion of the sharp transition between tropospheric and stratospheric regimes. This diagnostic facilitates the understanding of a finite chemical transition layer that encompasses the tropopause, with partly tropospheric, partly stratospheric character and allows to derive the transition region depth (Pan et al., 2007).

In this paper, the theory of the correlation between a tropospheric and a stratospheric tracer is applied to the TTL, and used to identify the chemical transition across the tropical tropopause, using both the $\mathrm{H}_{2} \mathrm{O}-\mathrm{O}_{3}$ and $\mathrm{CO}-\mathrm{O}_{3}$ relationships. Since the structure found in the form of tracer-tracer scatterplots can strongly reflect sampling (Hegglin and Shepherd, 2007), the use of joint probability density functions (PDFs) is in some circumstances preferable. Maxima in the joint PDFs indicate the regions where mixing is favoured and irreversible homogenization likely occurs, similar to maxima found in 1-D PDFs of stratospheric tracers, which indicate the presence of the well mixed regions; minima in the joint PDFs are found in the regions where mixing can be limited, similar to the minima found in 1-D PDFs of stratospheric tracers, which indicate the presence of barriers to mixing 

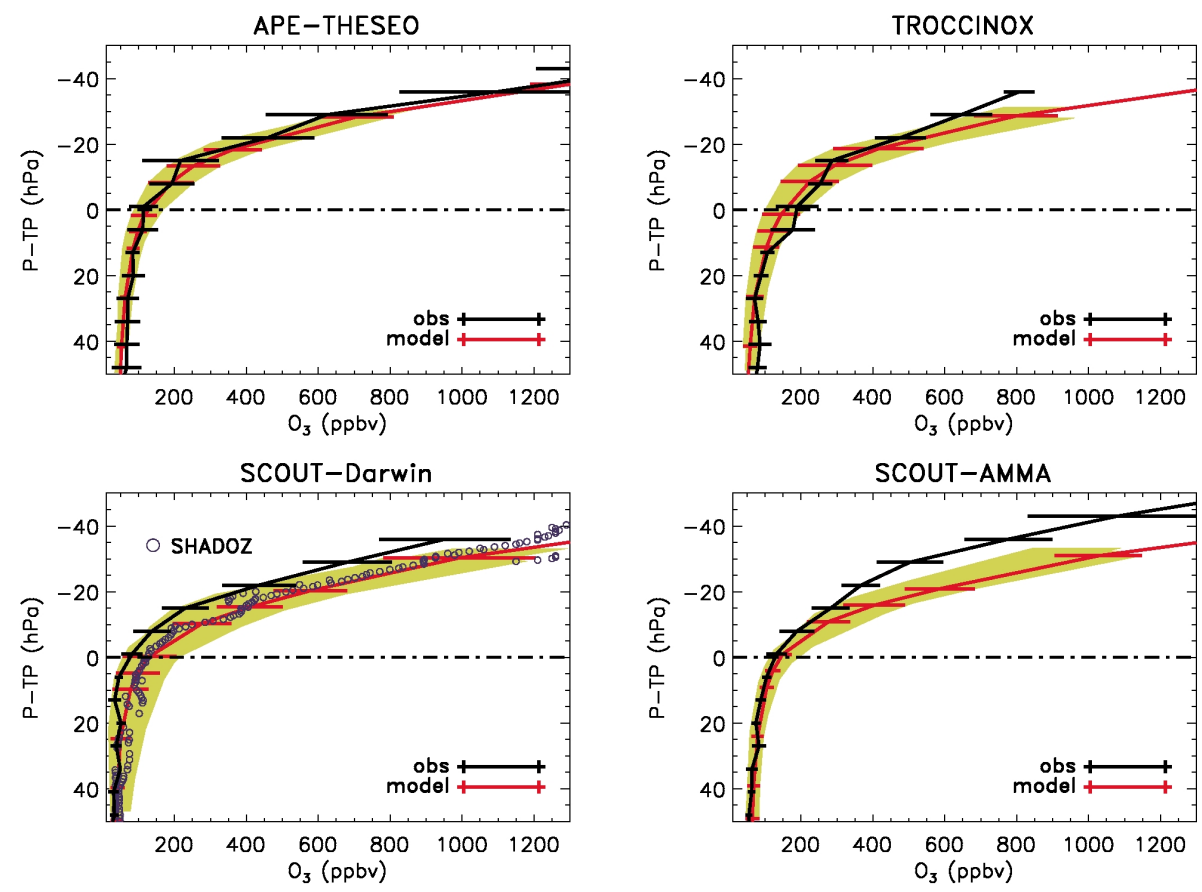

Fig. 3. Mean vertical profiles of $\mathrm{O}_{3}$ mixing ratios with standard deviations as a function of pressure relative to the to the thermal tropopause (TP=Tropopause Pressure) for M55-Geophysica campaigns (black line) and ECHAM5/MESSy (red line). For the model we have reported the line corresponding to the year having the same QBO phase of the campaign year. The shaded area includes the three model years with their standard deviations. The dash-dotted black line denotes the thermal tropopause pressure $(0 \mathrm{hPa})$. Blue circles in the bottom left plot indicate the measurements performed over the Fiji Islands in the time period corresponding to the SCOUT-Darwin campaign by ozonosondes belonging to the SHADOZ network.

(Sparling, 2000; Neu et al., 2003; Hegglin and Shepherd, 2007). An example on the use of the tracer-tracer PDFs is given in Sect. 5.2 for the pair $\mathrm{H}_{2} \mathrm{O}-\mathrm{O}_{3}$.

\subsection{Data handling}

For the observations, the chemicals concentrations measured during the Geophysica flights have been averaged within the geographical box (see Fig. 1) and through the duration (about one month) of each campaign in order to obtain a unique observed profile.

For the model as well, one unique averaged vertical profile for each species has been considered for each of the three model years and within the same regional boxes. However, we have not focused on the model interannual variability and the observed mean vertical profile of each species has been compared to the modelled one using the criterion of matching the observed QBO phase with the QBO internally generated by the model (see also Sect. 2.2). This to avoid that the discrepancies between the observed and modelled vertical profiles of the species analyzed may arise from comparing profiles representative of a different QBO, that is one of the principal sources of year-to-year variability in ozone, nitrous oxide, and other trace substances (e.g. Baldwin et al., 2001; Witte et al., 2008).

\section{Measured versus modelled vertical profiles and rela- tive gradients}

In this section, we analyze the mean vertical behaviour of ozone (Fig. 3), water vapour and temperature (Fig. 4), and nitrous oxide (Fig. 5) from each campaign observations (black lines) and the model data (red lines). Figure 6 shows the relative vertical ozone and $\mathrm{CO}$ gradients and the vertical profiles of static stability, $N^{2}$. The shaded green area in the figures includes the mean vertical tracer profiles or gradients from the three model years, and the dash-dotted black line denotes the thermal tropopause pressure $(0 \mathrm{hPa})$. Each panel in Figs. 3, 4,5 , and 6 corresponds to the region and time period of each campaign.

\subsection{Ozone}

Ozone is a tracer frequently used for studies of the TTL and troposphere-stratosphere exchange in general (e.g. Folkins et al., 1999), due to the fact that it is much more abundant in the stratosphere than in the troposphere.

In both the modelled and observed vertical profiles shown in Fig. 3, an upper tropospheric regime, characterized by nearly constant and less than 100 ppbv ozone mixing ratios, a transition zone between about -15 and $15 \mathrm{hPa}$ in which 

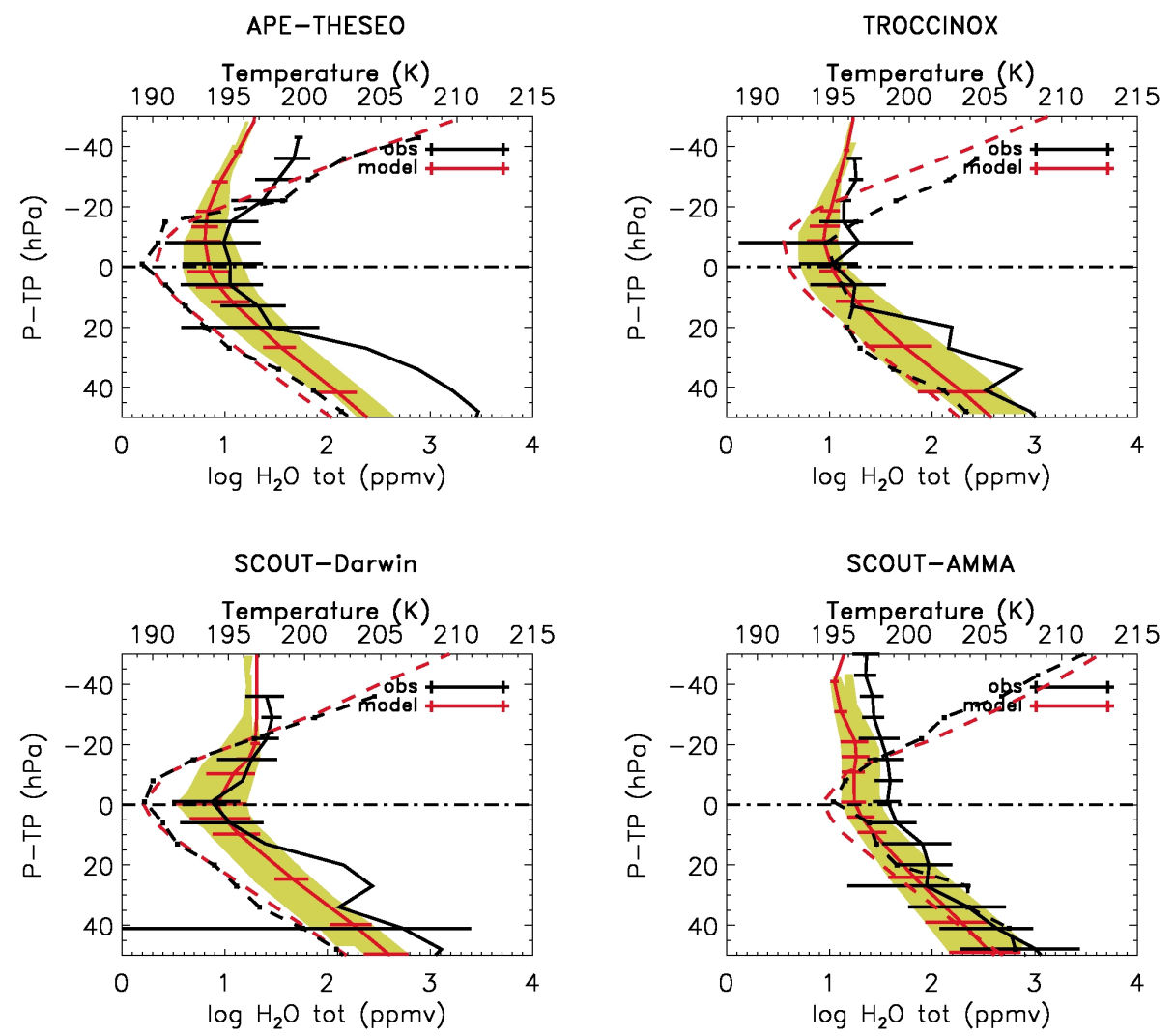

Fig. 4. The same as Fig. 3, for $\mathrm{H}_{2} \mathrm{O}$. A logarithmic scale has been used for $\mathrm{H}_{2} \mathrm{O}$ mixing ratios. Dashed lines denote the temperature profiles relative to the tropopause for the model (red) and the observations (black).
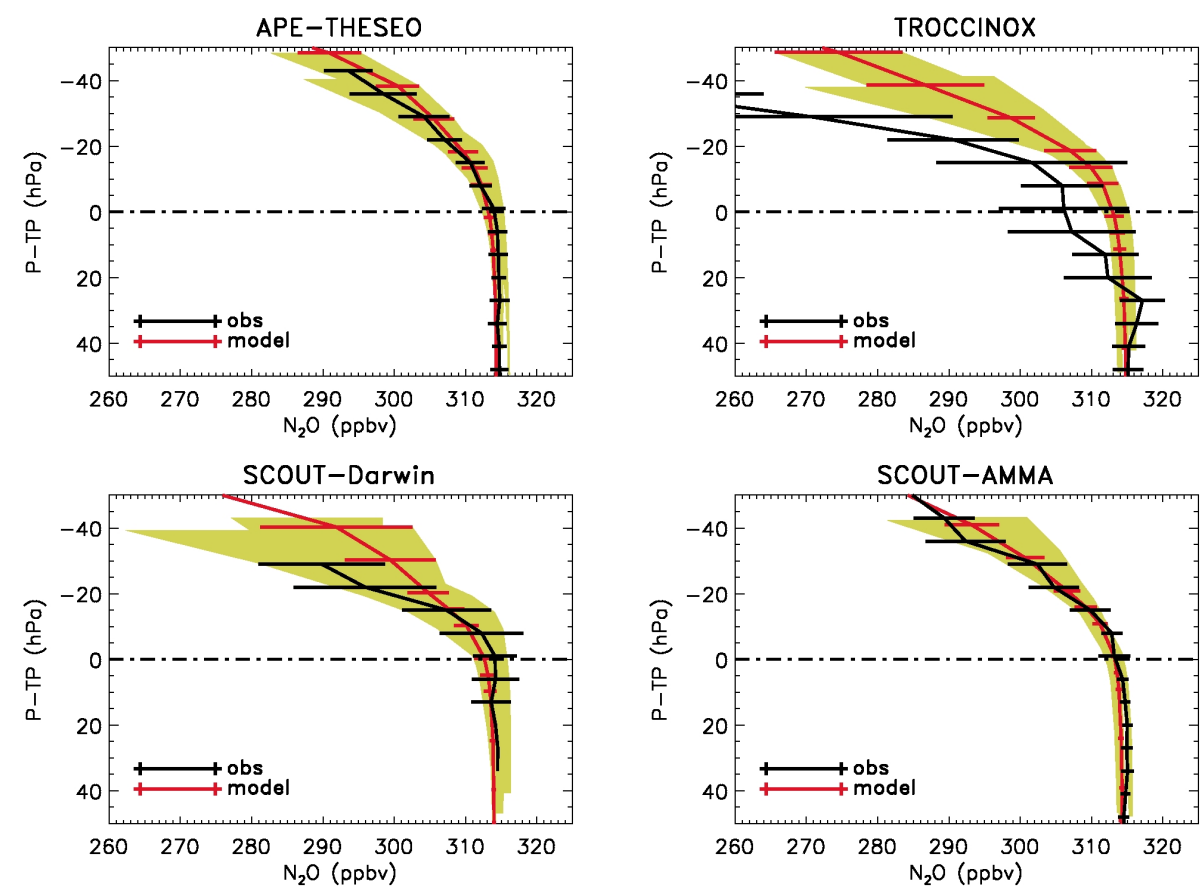

Fig. 5. The same as Fig. 3, for $\mathrm{N}_{2} \mathrm{O}$. 

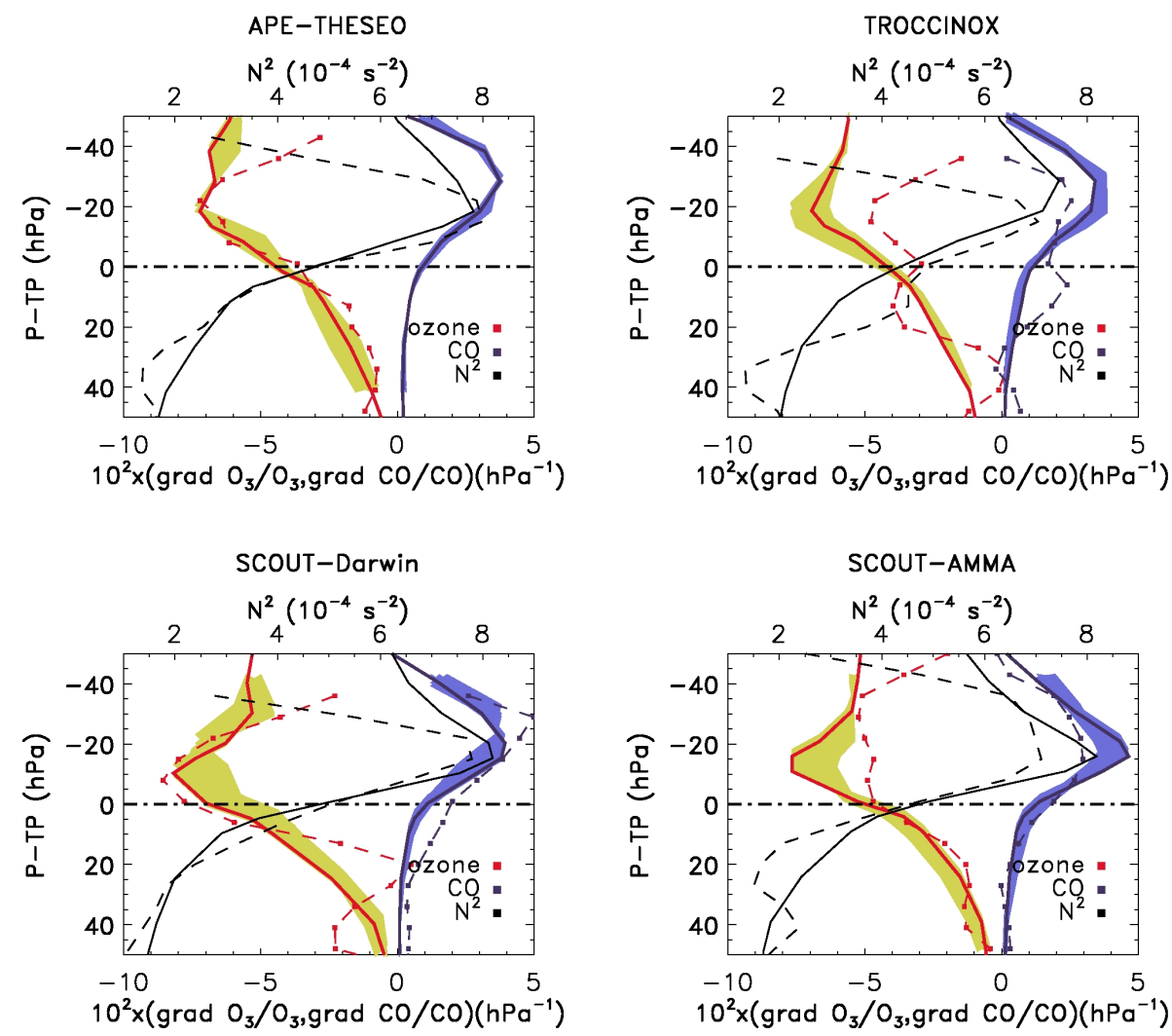

Fig. 6. Relative vertical ozone and CO gradients (ratio between the tracer gradient and its concentration) in tropopause coordinate ( $\mathrm{TP}=$ Tropopause Pressure) for M55-Geophysica campaigns (dashed lines) and ECHAM5/MESSy (solid lines). The vertical profiles of $N^{2}$ derived from the observations and the model are superimposed in black (dashed and solid lines, respectively).

air starts to assume some of the chemical characteristics of the stratosphere, and a lower stratospheric regime where ozone concentrations strongly increase with height due to photochemical production, are observed. Though these three regimes in the ozone vertical behaviour are visible in both the modelled and the observed ozone profiles, some differences occur between them, that are in part related to the details of each campaign.

During SCOUT-Darwin (bottom left panel) and SCOUTAMMA (bottom right panel), for instance, the model profiles are characterized by higher ozone mixing ratios then those observed throughout the entire vertical range considered (SCOUT-Darwin) and in the lower stratosphere (SCOUTAMMA), while the model-measurements agreement can be considered satisfactory in the case of APE-THESEO and TROCCINOX campaigns.

SCOUT-Darwin campaign took place during the premonsoon season, characterized by vigorous convection including the development of a mesoscale system known as "Hector" (Brunner et al., 2009). The large-scale origin of airmasses encountered in the TTL was different for the flights before and after 28 November. During the first half of the campaign, the air originated from the equatorial to north- ern subtropical Pacific and partly from the Northern Hemisphere. Strong ascent of these air masses suggests a significant contribution of clean marine ozone-poor boundary layer air, that, together with the occurrence of deep convection, could explain the low ozone concentrations measured in the TTL and lower stratosphere. During the second half, the air originated from the equatorial Indian Ocean and Indonesia and approached Darwin from the south thereby passing over the Australian continent, leading to enhanced ozone concentration. These different meteorological regimes have been analyzed in detail in Vaughan et al. (2008) and Brunner et al. (2009). Also Heyes et al. (2009) stresses the fact that, in general, elevated ozone concentrations can be attributed to sources over the Indonesia area, with greatly reduced concentrations showing a consistent origin from the tropical maritime Pacific region. In fact, ECHAM5/Messy ozone fields (not shown) are characterized by a strong latitudinal gradient in the TTL above northern sub-tropical Pacific preventing meridional transport; on the other hand, $\mathrm{O}_{3}$ shows a structure that is coherent with the transport pattern during the second half of the SCOUT-Darwin campaign. Model ozone fields actually give concentration mixing ratios in the SCOUT-Darwin region of about $300 \mathrm{ppbv}$ at $\theta=395 \mathrm{~K}$ and 
between $460 \mathrm{ppbv}$ and $500 \mathrm{ppbv}$ at $\theta=410 \mathrm{~K}$, that are higher than those actually measured during the campaign. We also report in the bottom left panel of Fig. 3, the ozone mixing ratios measured over the Fiji Islands $\left(18.13^{\circ} \mathrm{S}, 178.40^{\circ} \mathrm{E}\right)$ in the time period corresponding to the SCOUT-Darwin campaign by the ozonosondes belonging to the SHADOZ network (Thompson and Witte, 1999). It can be noticed that ECHAM5/MESSy agrees well with the SHADOZ data since these latter are much less influenced by convection north of Australia and by the "Hector" system than the aircraft measurements.

With regard to the model-measurements discrepancy in the case of SCOUT-AMMA, the ECHAM5/Messy ozone field averaged for the campaign at $410 \mathrm{~K}$ (not shown), seems to be driven by the zonal transport of ozone rich-air from the Pacific region by the tropical lower stratospheric jet, leading to a positive bias with respect to the observations. A similar bias has been observed by Brühl et al. (personal communication), that compare ozone vertical profiles measured during SCOUT-AMMA to ECHAM5/Messy simulations weakly nudged to ECMWF data between $700 \mathrm{hPa}$ and $200 \mathrm{hPa}$, indicating that the bias appears to be linked to the position of the subtropical barrier.

However, it is difficult to perform a deeper comparison of the lower stratospheric transport between ECHAM5/Messy and a single campaign observations, which represents a limitation of the approach presented here.

\subsection{Water vapour}

Water vapour is one of the key tracers for tropospherestratosphere exchange that led Brewer (1949) to conclude that air enters the stratosphere primarily in the tropics (see Sect. 1). In general, tropical water vapour concentration vertical profiles are characterized by large $\mathrm{H}_{2} \mathrm{O}$ values in the troposphere, a region with a pronounced tracer gradient with very low concentrations near the tropical tropopause, and smaller values in the lower stratosphere compared to the tropospheric mixing ratios. Very low values of the water vapour mixing ratio, in fact, extend upward from the minimum, which is only a few part per million by volume and far lower than typical tropospheric values, within a few kilometers of the tropical tropopause. The increase of water vapour concentrations above the minimum at tropopause levels can be due to in-mixing of stratospherically older air masses with increased water concentrations (due to oxidized methane), and, to a lesser degree, to in-situ methane oxidation or sporadic overshooting convection.

These distinct features in the TTL water vapour distribution are found in both the modelled and observed water vapour mixing ratio vertical profiles shown in Fig. 4. For each campaign analyzed, the modelled water vapour mixing ratios agree well with the observed ones, both above and below the tropopause. At the tropopause, the dehydration mechanism can be considered to be well captured by the model, even if a dry bias of about -1.5 ppmv can be identified in the model with respect to the observations in the case of SCOUT-AMMA (bottom right). For the other campaigns, the differences between the modelled and observed $\mathrm{H}_{2} \mathrm{O}$ mixing ratios at the tropopause are less significant and, anyhow, they are included in the interannual variability of the three model years (shaded area) and in the standard deviations of the observations. Lelieveld et al. (2007) compared results from the ECHAM5/MESSy1 CCM to satellite HALOE water vapour observations for the period 19962005 and, based on a model evaluation between $30^{\circ} \mathrm{S}$ and $30^{\circ} \mathrm{N}$ latitude, they found a dry bias in the model of about $-0.5 \mathrm{ppmv}$ in the $100 \mathrm{hPa}-75 \mathrm{hPa}$ region.

In general, the largest differences between the observed and modelled water vapour vertical profiles arise in the upper troposphere where, as expected, higher $\mathrm{H}_{2} \mathrm{O}$ concentrations are observed in convectively influenced regions. See, for instance, the observed $\mathrm{H}_{2} \mathrm{O}$ peak at $20 \mathrm{hPa}$ below the tropopause during SCOUT-Darwin. This is also confirmed by the high variability of the measured profiles, and a likely sampling bias of air masses which are influenced by local convection.

As mentioned above, convection can also occasionally enhance water vapour mixing ratios in the lowermost stratosphere. During the SCOUT-Darwin campaign, for instance, overshoot was measured during several flights (Corti et al., 2008), leading to the high $\mathrm{H}_{2} \mathrm{O}$ mixing ratios between -40 and $-20 \mathrm{hPa}$ shown in Fig. 4.

Figure 4 also shows that the tropopause (dash-dotted line) is dryer during the NH winter (APE-THESEO, SCOUTDarwin and TROCCINOX campaigns) while it is moister during the NH summer (SCOUT-AMMA). This also agrees with previous observational studies: MacKenzie et al. (2006), for example, combined the in-situ measurements of temperature, water vapour, total water, clear-sky relative humidity, and cloud from APE-THESEO to show evidence of active dehydration in the TTL down to very low water vapour mixing ratios (mean measured hygropause was $2.4 \mathrm{ppmv}$ ) over the western equatorial indian ocean.

As already mentioned in Sects. 1 and 2.2, $\mathrm{H}_{2} \mathrm{O}$ mixing ratios of air entering the tropical stratosphere vary seasonally in phase with the annual cycle of tropical tropopause temperature (Mote et al., 1996). To this regard, it is worth recalling that ECHAM5/Messy has a fast vertical advection that accelerates the vertical propagation of the water vapor signal (see Sect. 2.2), which also contributes to drive down the modelled water vapour in the TTL and lower stratosphere, as well as temperatures.

Temperature profiles for the model and the observations are also shown in Fig. 4 (dashed red and black lines, respectively). The model-measurements temperature comparison is satisfactory throughout the vertical range considered, for all the campaigns analyzed except SCOUT-AMMA and TROCCINOX, for which high temperature mean values are observed, respectively, in the upper troposphere and from 
$20 \mathrm{hPa}$ below the tropopause upward. The high temperature values measured during TROCCINOX, in particular, could be due to air-mass intrusion episodes from the subtropics into the tropical tropopause (Konopka et al., 2007), with a penetration area also characterized by increased water vapour mixing ratios (Fig. 4) and decreased $\mathrm{N}_{2} \mathrm{O}$ mixing ratio (as will be shown in Sect. 4.3). The PV fields at $\theta=380 \mathrm{~K} \mathrm{ob-}$ tained from the model (not shown) give a value of potential vorticity steadily equal or less than 3 PVU (absolute value) with a marked zonal structure; conversely, the PV calculated on the observations from the European Centre for Mediumrange Weather Forecasts (ECMWF) analysis spans over a large range of values in the TROCCINOX area (from less than 3 PVU to more than $9 \mathrm{PVU}$ ), corroborating the hypothesis of mid-latitude influence.

\subsection{Nitrous oxide}

$\mathrm{N}_{2} \mathrm{O}$ is a tracer that has a tropospheric source and a stratospheric sink, which makes it a chemical species of interest for TTL studies. While nitrous oxide is inert in the troposphere, it is removed by photolysis (90 percent) and reaction with excited oxygen atoms $\mathrm{O}\left({ }^{1} \mathrm{D}\right)$ at altitudes well above the tropopause. Therefore, air with low $\mathrm{N}_{2} \mathrm{O}$ values in the upper part of the TTL is expected to have some stratospherically older origin.

The measured and modelled vertical profiles of $\mathrm{N}_{2} \mathrm{O}$ in Fig. 5 show, in general, nearly uniform tropospheric concentrations and a decrease from the tropopause level upward. $\mathrm{N}_{2} \mathrm{O}$ is observed to have its largest stratospheric mixing ratios immediately above the tropical thermal tropopause, matching tropospheric values. The profiles shown in Fig. 5 moreover suggest that in-mixing of stratospheric air masses with low $\mathrm{N}_{2} \mathrm{O}$ concentrations is rare below the tropopause. The tropospheric value for $\mathrm{N}_{2} \mathrm{O}$ has increased of about $1 \mathrm{ppb} / \mathrm{yr}$ between 1999 and 2006 (updated from Prinn et al., 2000). However, since the model does not include the actual tropospheric growth rates, the observed $\mathrm{N}_{2} \mathrm{O}$ mixing ratios in the upper troposphere are generally higher then the simulated ones. The observed mean profiles have been scaled with a factor for each campaign, such that tropospheric observed values match those of the model.

The best model-measurements agreement is found for APE-THESEO (located in the inner tropics, see Fig. 1) and for SCOUT-AMMA. Because of the location at about the edge of the tropical pipe, the observations during TROCCINOX show a decrease of $\mathrm{N}_{2} \mathrm{O}$ at lower altitudes (Konopka et al., 2007), which has therefore reference to the penetration of air from higher latitudes. This is in agreement with the enhanced temperatures values and water vapour mixing ratios discussed in Sect. 4.2. Concerning the SCOUT-Darwin campaign, in the first-half period (exactly between 18-24 November) a Rossby wave breaking event occurred along the subtropical jet stream, that pushed filaments of midlatitude air deep into the tropics over Darwin (Vaughan et al., 2008;
Brunner et al., 2009), leading to layers of low $\mathrm{N}_{2} \mathrm{O}$ mixing ratios. Therefore, as already mentioned in Sect. 4.1 for ozone, the model agrees better with the observations representative of the second half of the SCOUT-Darwin campaign than those of the first half. As also pointed out in Sect. 4.2 for water vapour, it should not be excluded the influence of the model dynamics (fast vertical advection, see Sect. 2.2) on the reduced $\mathrm{N}_{2} \mathrm{O}$ layer in the TTL and lower stratosphere in ECHAM5/Messy respect to the observations, as evident during TROCCINOX and SCOUT-Darwin.

In the case of TROCCINOX and, despite the sparseness of observations of SCOUT-Darwin, the $\mathrm{N}_{2} \mathrm{O}$ gradient above the tropopause is sharper in the observations than in the model. Both observations and model data show a higher variability compared to the other campaigns, as denoted by the comparatively larger standard deviations.

\subsection{Tracer relative vertical gradients in the TTL}

In Fig. 6, the observed (dashed lines) and modelled (filled lines) relative vertical ozone gradients (red), relative vertical CO gradients (blue), and $N^{2}$ vertical profiles (black), in tropopause coordinates (see Sect. 3.1.1 and 3.1.2), are shown. The three quantities exhibit similar features. Both the relative vertical $\mathrm{CO}$ gradient and $N^{2}$ reveal a maximum above the tropopause, while at corresponding pressures the relative vertical $\mathrm{O}_{3}$ gradient exhibits a minimum. This is the level that marks the lower boundary of stratospheric regime where ozone concentrations steadily increase and $\mathrm{CO}$ concentrations decrease. Below the tropopause, the minimum in $N^{2}$ and maximum in relative vertical $\mathrm{O}_{3}$ gradient are also linked, and can be thought of as indicative of the lowermost level where the transition from tropospheric to stratospheric regime occurs.

The observations, though they are more scattered than the model data, generally confirm the picture illustrated by the model. For APE-THESEO, SCOUT-Darwin, and SCOUTAMMA, in particular, a satisfactory model-measurements agreement is found.

Table 3 resumes the values (in pressure, relative to the tropopause) of the top and bottom bounds of the troposphereto-stratosphere interface. Empty cells denote the cases where an evaluation is not straightforward.

The top can be identified by the minimum in the ozone relative gradient, the maximum in $\mathrm{CO}$ relative gradient, and the maximum in the $N^{2}$ vertical profile. This agrees with the study of Fueglistaler et al. (2009), that sets the top of the TTL at $70 \mathrm{hPa}$, which is also about the level of maximum static stability. The bottom, in a symmetric way and when possible, can be identified by the maximum in the ozone relative gradient, and the minimum in $\mathrm{CO}$ relative gradient and in the $N^{2}$ vertical profile. 
Table 3. Estimates of the transition layer Top and Bottom pressures (relative to the tropopause pressure) inferred from the relative vertical gradients of ozone and CO, and from the vertical profiles of $N^{2}$ (see Fig. 6), for the observations (Obs) and the model (Mod).

\begin{tabular}{|c|c|c|c|c|c|c|c|}
\hline & \multirow{2}{*}{$\begin{array}{l}\text { P-TP } \\
\mathrm{hPa}\end{array}$} & \multicolumn{2}{|c|}{$\operatorname{grad}\left(\mathrm{O}_{3}\right) / \mathrm{O}_{3}$} & \multicolumn{2}{|c|}{$\operatorname{grad}(\mathrm{CO}) / \mathrm{CO}$} & \multicolumn{2}{|l|}{$N^{2}$} \\
\hline & & Obs & Mod & Obs & Mod & Obs & Mod \\
\hline \multirow[t]{2}{*}{ APE-THESEO } & Top & $\sim-20$ & $\sim-20$ & no data & $-25 /-30$ & $\sim-15$ & $\sim-15$ \\
\hline & Bottom & 35 & & no data & & $35 / 40$ & \\
\hline \multirow[t]{2}{*}{ TROCCINOX } & Top & -15 & $-15 /-20$ & $-20 /-25$ & $-25 /-30$ & $\sim-15$ & $\sim-30$ \\
\hline & Bottom & 35 & $\sim 40$ & 35 & & $35 / 40$ & \\
\hline \multirow[t]{2}{*}{ SCOUT-Darwin } & Top & $\sim-10$ & $\sim-10$ & -30 & -20 & $\sim-15$ & $\sim-15$ \\
\hline & Bottom & 20 & $\sim 40$ & $15 / 20$ & & & \\
\hline \multirow[t]{2}{*}{ SCOUT-AMMA } & Top & & $\sim-15$ & -15 & -15 & $\sim-15$ & $\sim-15$ \\
\hline & Bottom & $25 / 30$ & $\sim 40$ & $25 / 30$ & & $25 / 30$ & \\
\hline
\end{tabular}

\section{Tracer-tracer correlations in the TTL}

In this section, the TTL morphology is investigated from the perspective of chemical composition through the use of tracer-tracer correlations. Working in the tracer-tracer space is useful to reveal characteristic tracer features of different air masses due to specific dynamical and transport processes. In the extra-tropics, this approach has been widely used to derive the transition layer depth in terms of the distance between its top and bottom from the thermal or dynamical tropopause (Pan et al., 2007; Hegglin et al., 2009). However, only few applications to the TTL can be found in the literature (e.g. Hegglin et al., 2009).

As mentioned in Sect. 3.1.3, the correlations in the tropics are expected to have the classical " $L$ " shape, due to the small cross-tropopause mixing and slow ascent of the air parcels.

In particular, the relationships between the pairs $\mathrm{CO}-\mathrm{O}_{3}$ and $\mathrm{H}_{2} \mathrm{O}-\mathrm{O}_{3}$ will be investigated (Figs. 7 and 8, respectively) using the tracer mixing ratios measured during the four tropical Geophysica campaigns and the ones reproduced by ECHAM5/MESSy. The model data include all the points collocated within the four red boxes shown in Fig. 1.

The tracer-tracer correlation points in Figs. 7 and 8 have been colored according to $12 \mathrm{hPa}$-thick pressure intervals defined a priori. The PDF of the $\mathrm{H}_{2} \mathrm{O}-\mathrm{O}_{3}$ correlation is also shown in Fig. 9.

\section{$5.1 \mathrm{CO}_{\text {vs. }} \mathrm{O}_{3}$}

Figure 7 shows the correlation of $\mathrm{CO}$ with $\mathrm{O}_{3}$ for ECHAM5/MESSy (left column) and the observations from only three of the four campaigns considered in this study (TROCCINOX, SCOUT-Darwin and SCOUT-AMMA, in the right column from the top to the bottom), since $\mathrm{CO}$ data were not measured during APE-THESEO.

In general, the $\mathrm{CO}-\mathrm{O}_{3}$ relationships shown in Fig. 7, rather then the " $L$ " shape observed in the extra-tropical UT/LS, form a smoother curve. This is mainly due to the chemical lifetime of $\mathrm{CO}$, which is comparable to the transport timescales on which troposphere-to-stratosphere transport
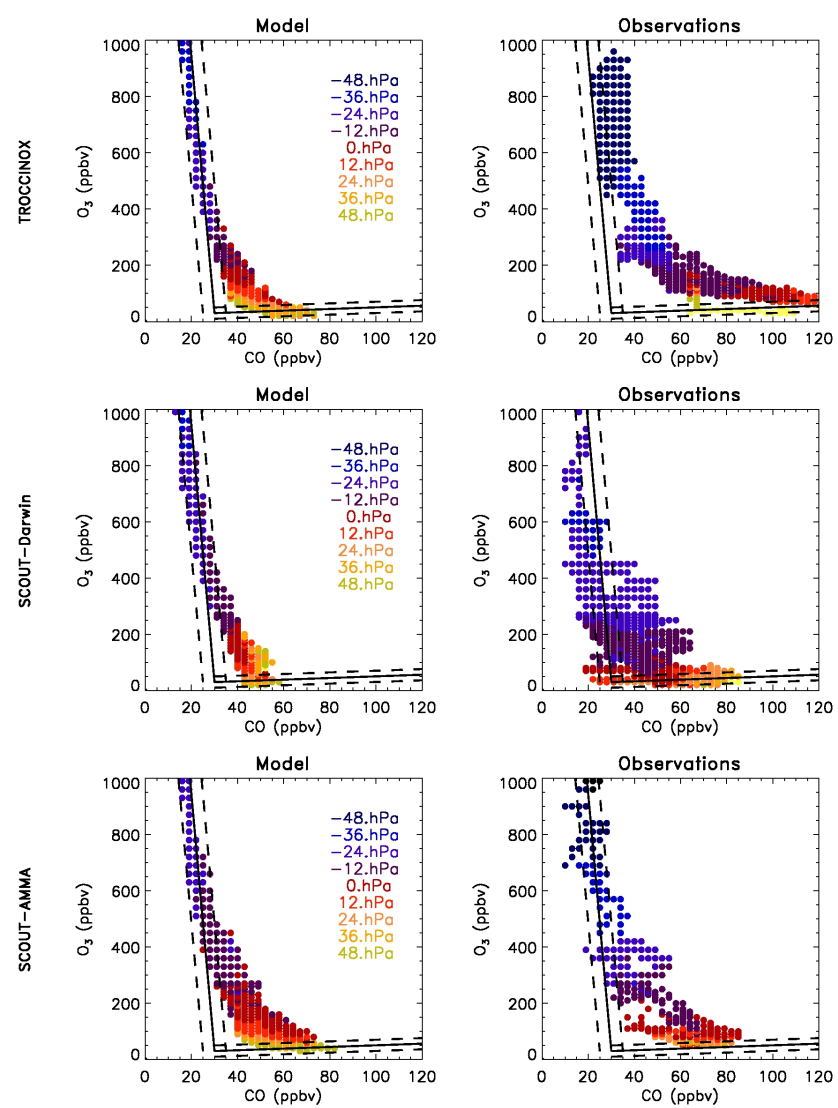

Fig. 7. $\mathrm{CO}-\mathrm{O}_{3}$ correlations for ECHAM5/MESSy (left column) and the observations (right column), relative to the regions and time periods of TROCCINOX, SCOUT-Darwin, and SCOUT-AMMA campaigns (from top to bottom), divided by color according to $12 \mathrm{hPa}$-thick pressure ranges whose central value is indicated in the legend. Black solid lines indicate fits (as explained in the text) to tropospheric and stratospheric branches. 

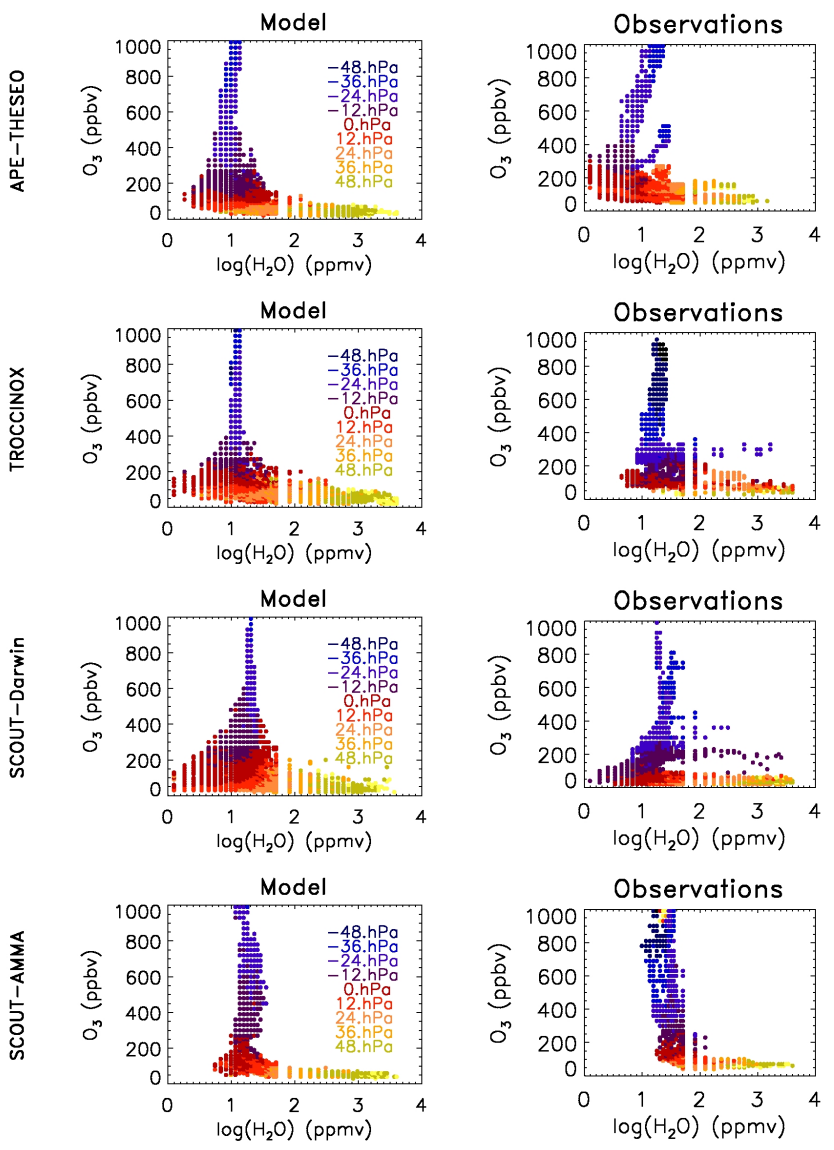

Fig. 8. $\mathrm{H}_{2} \mathrm{O}-\mathrm{O}_{3}$ correlations for ECHAM5/MESSy (left column) and the observations (right column), relative to the regions and time periods of APE-THESEO, TROCCINOX, SCOUT-Darwin, and SCOUT-AMMA campaigns (from top to bottom), divided by color according to $12 \mathrm{hPa}$-thick pressure ranges whose central value is indicated in the legend.

occurs and makes CO a "pure" transport tracer (Hegglin et al., 2009).

The black solid lines in Fig. 7 represent the empirical stratospheric and tropospheric $\mathrm{CO}-\mathrm{O}_{3}$ relationships, derived using data points with $\mathrm{CO}<30 \mathrm{ppbv}$ for stratospheric and $\mathrm{O}_{3}<70 \mathrm{ppbv}$ for tropospheric. $\mathrm{CO}$ decreases from a range of tropospheric concentrations depending on the campaign, towards its stratospheric steady value of around $30 \mathrm{ppbv}$, reached at about $10-15 \mathrm{hPa}$ above the tropopause.

Overall agreement is found in the case of SCOUTAMMA between the modelled (bottom left panel) and observed (bottom right panel) $\mathrm{CO}-\mathrm{O}_{3}$ correlation. The transition region between tropospheric and stratospheric regimes, in fact, is characterized by similar ozone mixing ratios (from $\sim 80 \mathrm{ppbv}$ to $\sim 450 \mathrm{ppbv}$ ) and $\mathrm{CO}$ mixing ratios (from $\sim 30 \mathrm{ppbv}$ to $\sim 80 \mathrm{ppbv}$ ). For TROCCINOX (first row panels) and SCOUT-Darwin campaigns (middle panels), on the contrary, some differences between the model and the observations can be noticed. The transition region for both these
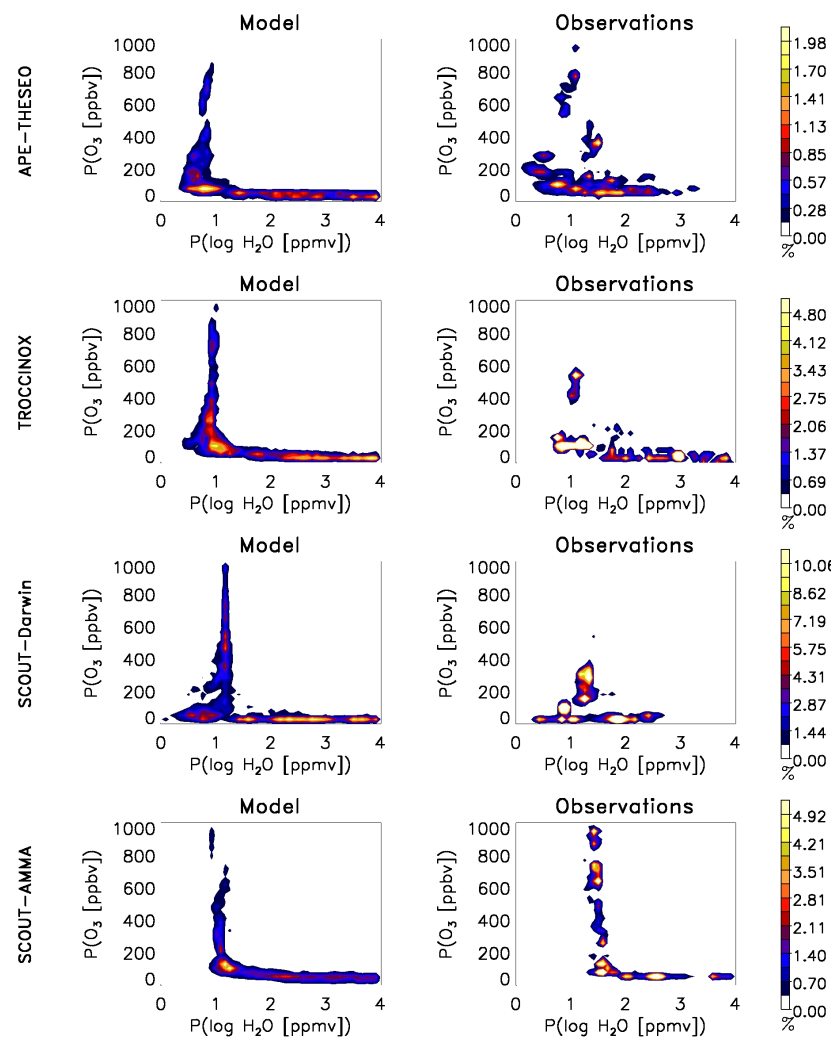

Fig. 9. Joint probability distribution functions (PDFs) of the $\mathrm{H}_{2} \mathrm{O}$ $\mathrm{O}_{3}$ correlation for the region and time period of each campaign. Left: ECHAM5/MESSy; right: observations.

campaigns, as deduced from the model data, occurs for a smaller range of $\mathrm{O}_{3}$ values (from $\sim 90 \mathrm{ppbv}$ to $\sim 350 \mathrm{ppbv}$ ) as well as of $\mathrm{CO}$ values (from $\sim 30 \mathrm{ppbv}$ to $\sim 60 \mathrm{ppbv}$ ) than those emerging from the observations. The structure of the transition region inferred from TROCCINOX observations, for instance, shows the clear impact of in-mixing from midlatitudes (due to the fact that this campaign was performed close to the subtropics), which alters and shifts the overall $\mathrm{CO}-\mathrm{O}_{3}$ scatter plot: it lies nearly completely outside the empirical no-mixing lines and is characterized by higher values of $\mathrm{CO}$ (from $\sim 30 \mathrm{ppbv}$ to $>120 \mathrm{ppbv}$ ) and typically stratospheric $\mathrm{O}_{3}$ mixing ratios.

\section{$5.2 \quad \mathrm{H}_{2} \mathrm{O}$ vs. $\mathrm{O}_{3}$}

Figure 8 shows the correlation of $\mathrm{H}_{2} \mathrm{O}$ with $\mathrm{O}_{3}$ for ECHAM5/MESSy (left column) and the observations from the four campaigns analyzed (APE-THESEO, TROCCINOX, SCOUT-Darwin and SCOUT-AMMA, in the right column from the top to the bottom).

In spite of inter-campaigns differences, $\mathrm{H}_{2} \mathrm{O}-\mathrm{O}_{3}$ correlations have the theoretical tropical " $L$ " shape, that results from the small cross-tropopause mixing, with respect to the extratropics (Hegglin et al., 2009), and small ascent of air parcels 
that experience dehydration at tropopause levels. Since $\mathrm{H}_{2} \mathrm{O}$ is influenced by microphysical mechanisms, it can be considered a less pure tracer than CO. Moreover, the transition between the tropospheric and the stratospheric branches occurs at lower $\mathrm{H}_{2} \mathrm{O}$ mixing ratios during winter (APETHESEO, TROCCINOX, SCOUT-Darwin campaigns) than during summer (SCOUT-AMMA campaign), reflecting the seasonal cycle in tropopause temperatures. The transition occurs around the thermal tropopause or slightly below and involves a layer which is no more than $25-30 \mathrm{hPa}$ thick, depending on the campaign.

For SCOUT-AMMA (bottom panels in Fig. 8), both model data and the measurements lie on well separated tropospheric and stratospheric branches with a relatively narrow transition zone in between $(\sim 15 \mathrm{hPa}$ thick). From a chemical point of view the transition region includes $\mathrm{H}_{2} \mathrm{O}$ mixing ratios from about 2 to 5 ppmv (model) and 3 to 7 ppmv (observations), in agreement with the ECHAM5/MESSy dry bias discussed in Sect. 4.2, and $\mathrm{O}_{3}$ mixing ratios less then $200 \mathrm{ppbv}$, in both model and observations.

For the other three campaigns, besides the evidence of dehydration at tropopause levels, which is a common feature in both modelled and observed $\mathrm{H}_{2} \mathrm{O}-\mathrm{O}_{3}$ scatter plots, the situation is more complicated than for SCOUT-AMMA. For SCOUT-Darwin, for instance, the scatter plot shows a noticeable region of mixing (for $\mathrm{H}_{2} \mathrm{O}$ mixing ratios $>4 \mathrm{ppmv}$ ) in the model, and a less extended region of mixing with more coherent hydrated layers around 12 and $24 \mathrm{hPa}$ above the tropopause in the observations.

Figure 9 shows the two-dimensional PDFs of the $\mathrm{H}_{2} \mathrm{O}$ $\mathrm{O}_{3}$ pair calculated from the model (left) and the observations (right) relative to the four campaigns area and time period. The data were binned into $\mathrm{H}_{2} \mathrm{O}$ and $\mathrm{O}_{3}$ bins with widths of $0.1 \mathrm{ppmv}$ and $25 \mathrm{ppbv}$, respectively, and weighted with the number of measurements found in the corresponding pressure bin. The PDFs have then been normalized with respect to the total number of measurements used in the evaluation. This normalization also allows to calculate the observed PDFs with a vertical resolution which is comparable to the model vertical resolution.

The structure of the joint PDFs is similar in the model and the observations and is characterized by the three separated regimes, also seen in the $\mathrm{H}_{2} \mathrm{O}-\mathrm{O}_{3}$ scatter plots shown in Fig. 8, that draw the above-mentioned " $L$ " shape. The tropospheric regime is characterized by a nearly constant $\mathrm{O}_{3}$ value and variable $\mathrm{H}_{2} \mathrm{O}$ mixing ratios, while the stratospheric regime is characterized by a nearly constant $\mathrm{H}_{2} \mathrm{O}$ value and variable $\mathrm{O}_{3}$ mixing ratios. In the region lying between the two branches, there is a certain probability to find, at the same time, relatively high ozone and high $\mathrm{H}_{2} \mathrm{O}$ mixing ratios, both being, however, lower than the pure stratospheric and pure lower tropospheric values, respectively.

The use of tracer-tracer PDFs is helpful to assess the statistical relevance of the observational sampling, and can be in some circumstances preferable to the use of tracer-tracer scatter plots. In the case of TROCCINOX and SCOUTDarwin, for instance, the joint PDFs obtained from the measurements (right column) show, even though less extended in terms of water vapour mixing ratio values, the hydrated layers above the tropopause appearing in the $\mathrm{H}_{2} \mathrm{O}-\mathrm{O}_{3}$ scatter plot shown in Fig. 8. This suggests that the fraction of measurements influenced by local processes as convection (particularly for SCOUT-Darwin, for which a high probability is found in that region) has a certain relevance and can have an impact on the statistical properties of the $\mathrm{H}_{2} \mathrm{O}-\mathrm{O}_{3}$ correlation.

\section{Conclusions}

The TTL is a region of interest because it is the interface between the very different dynamical and chemical tropospheric and stratospheric regimes and because it determines the entry of atmospheric tracers such as water vapour and the short-lived substances in the stratosphere.

A decade of observational activity in the tropical UT/LS with high resolution in-situ instruments on board stratospheric research aircrafts has built up a considerable dataset that allows to partially overcome the drawback due to the spatial and temporal sparseness of such kind of data, making use of appropriate diagnostics that capture the key aspects of TTL transport and interrelationships between different species.

A good representation of the TTL in Chemistry Climate Models is a challenge, due to the difficulty to understand and correctly simulate the TTL radiative, chemical and dynamical processes and their connections. The vertical resolution of CCMs is often not adequate to capture the small-scale variability of the tracer fields and processes in this relatively thin layer, and the horizontal resolution can also be a limit, since convection that transport compounds from the emission sources to the upper troposphere is parameterized.

In this paper, a suite of specific diagnostics have been applied to the in-situ high-resolution measurements performed on board the aircraft Geophysica during the four tropical campaigns (APE-THESEO, TROCCINOX, SCOUTDarwin, SCOUT-AMMA) and to the ECHAM5/MESSy CCM data. These diagnostics consist of the vertical mixing ratio profiles and relative gradients of selected compounds (ozone, water vapour, nitrous oxide, and carbon monoxide) in tropopause coordinates and on tracer-tracer correlations $\left(\mathrm{CO}-\mathrm{O}_{3}, \mathrm{H}_{2} \mathrm{O}-\mathrm{O}_{3}\right)$. They corroborate the existence of a tropical tropopause transition region and allow to characterize it in terms of chemical vertical distribution, thickness, and variability. They moreover facilitate comparisons of observational and model data (Pan et al., 2007) and provide a suite of tools for testing the ability of CCMs to simulate the TTL structure.

The analysis of the $\mathrm{O}_{3}, \mathrm{H}_{2} \mathrm{O}$, and $\mathrm{N}_{2} \mathrm{O}$ vertical profiles, of $\mathrm{O}_{3}$ and $\mathrm{CO}$ relative vertical gradients, and of $N^{2}$ vertical pro- 
file, in tropopause coordinates, has revealed the existence of a finite tropical transition layer about the tropopause having characteristics of both the troposphere and the stratosphere. The transition between the two regimes occurs within this layer where the aforementioned species exhibit their greatest gradient changes (see Figs. 3, 4, 5, and 6). The TTL encompasses the thermal tropopause that acts as a barrier to vertical mixing.

The vertical $N^{2}$ profile and the relative vertical ozone and $\mathrm{CO}$ gradients are found to have similar structures, from which the upper and lower bounds of the transition layer can be estimated (Fueglistaler et al., 2009). These levels are summarized in Table 3, for the model and the observations. The top and bottom bounds are located, respectively, at about $15 \mathrm{hPa}$ above the tropopause $(400-410 \mathrm{~K})$ and, on average, at $35 \mathrm{hPa}$ below the tropopause $(\sim 360 \mathrm{~K})$, as inferred from the maximum and minimum values of $N^{2}$, showing a good agreement between the model and the observations. Using the relative vertical ozone gradient, the top and the bottom bounds are on average located at about $15 \mathrm{hPa}$ above and $35 \mathrm{hPa}$ below the tropopause, respectively, while using the relative vertical CO gradient at about $23 \mathrm{hPa}$ above $(\sim 425 \mathrm{~K})$ and $27 \mathrm{hPa}$ below $(\sim 365 \mathrm{~K})$ the tropopause. For both diagnostics, the model-measurements agreement is in most cases good.

The existence of a region where the tropospheric and stratospheric regimes in chemicals distribution co-exist is enhanced using the correlation between a tropospheric (typically $\mathrm{CO}$ or $\mathrm{H}_{2} \mathrm{O}$ ) and a stratospheric (typically $\mathrm{O}_{3}$ ) tracer. In the tropics, a classical $L$ shape is found in the $\mathrm{H}_{2} \mathrm{O}-\mathrm{O}_{3}$ correlation, where vertical transport across the tropopause is mainly upward into the overworld and the low temperatures at the tropopause determine the dehydration of air entering the stratosphere. On the other hand, the $\mathrm{CO}-\mathrm{O}_{3}$ correlation has a smoother shape than the $\mathrm{H}_{2} \mathrm{O}-\mathrm{O}_{3}$ relationship , because $\mathrm{CO}$ is a purer tracer for transport than $\mathrm{H}_{2} \mathrm{O}$ in this region (Hegglin et al., 2009).

Depending on the location in the tropics and on the season, the TTL derived from $\mathrm{H}_{2} \mathrm{O}-\mathrm{O}_{3}$ extends roughly from -20 to $20 \mathrm{hPa}$ (P-TP coordinate), being thinner in summer than in winter. The TTL derived from $\mathrm{CO}_{-} \mathrm{O}_{3}$ is in general thinner than the one derived from the $\mathrm{H}_{2} \mathrm{O}-\mathrm{O}_{3}$ pair, extending the results by Hegglin et al. (2009) to the tropics. In addition to tracer-tracer correlations, use of their joint probability density functions has demonstrated to be an useful means to provide a detailed picture of key aspects of transport across the tropopause (e.g. Hegglin and Shepherd, 2007), also accounting for observational sampling biases (see Fig. 9).

The comparison between ECHAM5/MESSy and the aircraft observations has shown that the model is able to reproduce the background features of the TTL in different seasons and regions. However, the model can not resolve some particular features occurred especially during the TROCCINOX and SCOUT-Darwin campaign, resulting in the disagreement between the modelled and observed mean vertical profiles of ozone, nitrous oxide and water vapour, especially around the tropopause and in the lower stratosphere. Furthermore, as shown in Sect. 2.2 in the analysis of modelled water vapour tape recorder and comparison with MLS observations (Liu et al., 2007), the model turns out to have a too fast vertical advection, which is in agreement with the overall behaviour of CCMs described by Eyring et al. (2006). The accelerated phase speed in ECHAM5/Messy is in part responsible for driving down temperatures and water vapour, and causing the $\mathrm{N}_{2} \mathrm{O}$ bias between the model and observations.

Moreover, the non homogeneous observational sampling leads to less smoothed and more scattered mean vertical profiles/gradients in the observations than in the model.

Even if restricted to a single CCM and the M55 observational dataset, the analyses performed in this paper show that the use of specific diagnostics for the analysis of different datasets can highlight the average features of the TTL vertical structure and allow to estimate, in most cases, the transition layer thickness. Our evaluation is the first to apply vertical tracer gradients and tracer-tracer correlations to characterize the structure and depth of the TTL using aircraft data. Prior studies using these diagnostics were applied to satellite data (Hegglin et al., 2009) or a smaller suite of diagnostics to aircraft data (Hoor et al., 2004; Pan et al., 2004; Pan et al., 2007) with focus on the ExTL. The suite of diagnostics presented in this paper can contribute to give representativeness to geographically sparse or limited in-situ observations, and can be profitably applied to satellite data, as extensively done in the extra-tropics, and to CCM data.

Acknowledgements. Authors would like to thank M. I. Hegglin for providing very useful suggestions.

Authors acknowledge the partial support of the EC SCOUT-O3 Integrated Project (505390- GOCE-CT-2004). Chiara Cagnazzo and Elisa Manzini acknowledge the partial support of Centro Euro-Mediterraneo per i Cambiamenti Climatici. The model simulation were performed at ECMWF, under the Special Project on Middle Atmosphere Modelling.

Edited by: R. MacKenzie

\section{References}

Andrews, A. E., Boering, K. A., Daube, B. C., Wofsy, S. C., Hintsa, E. J., Weinstock, E. M., and Bui, T. P.: Empirical age spectra for the lower tropical stratosphere from in situ observations of $\mathrm{CO}_{2}$ : Implications for stratospheric transport, J. Geophys. Res., 104(D21), 26581-2659, 1999.

Baldwin, M. P., Gray, L. J., Dunkerton, T. J., Hamilton, K., Haynes, P. H., Randel, W. J., Holton, J. R., Alexander, M. J., Hirota, I., Horinouchi, T., Jones, D. B. A., Kinnersley, J. S., Marquardt, C., Sato, K., and Takahashi, M.: The Quasi-Biennial Oscillation, Rev. Geophys., 39(2), 179-229, 2001.

Birner, T: Fine-scale structure of the extratropical tropopause region, J. Geophys. Res., 111, D04104, doi:10.1029/2005JD006301, 2006. 
Brewer, A. W.: Evidence for a world circulation provided by the measurements of helium and water vapour distribution in the stratosphere, Q. J. Roy. Meteorol. Soc., 75, 351-363, 1949.

Brunner, D., Siegmund, P., May, P. T., Chappel, L., Schiller, C., Müller, R., Peter, T., Fueglistaler, S., MacKenzie, A. R., Fix, A., Schlager, H., Allen, G., Fjaeraa, A. M., Streibel, M., and Harris, N. R. P.: The SCOUT-O3 Darwin Aircraft Campaign: rationale and meteorology, Atmos. Chem. Phys., 9, 93-117, 2009, http://www.atmos-chem-phys.net/9/93/2009/.

Cagnazzo, C., Manzini, E., Giorgetta, M. A., Forster, P. M. De F., and Morcrette, J. J.: Impact of an improved shortwave radiation scheme in the MAECHAM5 General Circulation Model, Atmos. Chem. Phys., 7, 2503-2515, 2007,

http://www.atmos-chem-phys.net/7/2503/2007/.

Chaboureau, J.-P., Cammas, J.-P., Duron, J., Mascart, P. J., Sitnikov, N. M., and Voessing, H.-J.: A numerical study of tropical crosstropopause transport by convective overshoots, Atmos. Chem. Phys., 7, 1731-1740, 2007,

http://www.atmos-chem-phys.net/7/1731/2007/

Corti, T., Luo, B. P., de Reus, M., Brunner, D., Cairo, F., Mahoney, M. J., Martucci, G., Matthey, R., Mitev, V., dos Santos, F. H., Schiller, C., Shur, G., Sitnikov, N. M., Spelten, N., Voessing, H. J., Borrmann, S., and Peter, T.: Unprecedented evidence for deep convection hydrating the tropical stratosphere, Geophys. Res. Lett., 35, L10810, doi:10.1029/2008GL033641, 2008.

Eyring V., Butchart, N., Waugh, D. W., Akiyoshi, H., Austin, J., Bekki, S., Bodeker, G. E., Boville, B. A., Brühl, C., Chipperfield, M. P., Cordero, E., Dameris, M., Deushi, M., Fioletov, V. E., Frith, S. M., Garcia, R. R., Gettelman, A., Giorgetta, M. A., Grewe, V., Jourdain, L., Kinnison, D. E., Mancini, E., Manzini, E., Marchand, M., Marsh, D. R., Nagashima, T., Newman, P. A., Nielsen, J. E., Pawson, S., Pitari, G., Plummer, D. A., Rozanov, E., Schraner, M., Shepherd, T. G., Shibata, K., Stolarski, R. S., Struthers, H., Tian, W., Yoshiki, M: Assessment of temperature, trace species, and ozone in chemistry-climate model simulations of the recent past, J. Geophys. Res., 111, D22308, doi:10.1029/2006JD007327, 2006.

Folkins, I., Loewenstein, M., Podolske, J., Oltmans, S. J., and Proffitt, M.: A barrier to vertical mixing at $14 \mathrm{~km}$ in the tropics: Evidence from ozonesondes and aircraft measurements, J. Geophys. Res., 104(D18), 22095-22102, 1999.

Froyd, K. D., Murphy, D. M., Sanford, T. J., Thomson, D. S., Wilson, J. C., Pfister, L., and Lait, L.: Aerosol composition of the tropical upper troposphere, Atmos. Chem. Phys., 9, 4363-4385, 2009, http://www.atmos-chem-phys.net/9/4363/2009/.

Fueglistaler, S., Bonazzola, M., Haynes, P., and Peter, Th.: Stratospheric water vapor predicted from the Lagrangian temperature history of air entering the stratosphere in the tropics, J. Geophys. Res., 110, D08107, doi:10.1029/2004JD005516, 2005.

Fueglistaler, S., Dessler, A. E., Dunkerton, T. J., Folkins, I., Fu, Q., and Mote, P. W.: Tropical tropopause layer, Rev. Geophys., 47, RG1004, doi:10.1029/2008RG000267, 2009.

Gettelman, A. and Forster, P. M. de F.: A climatology of the tropical tropopause layer, J. Meteorol. Soc. Jpn., 80, 911-924, 2002.

Gettelman, A. and Birner, T.: Insights into Tropical Tropopause Layer processes using global models, J. Geophys. Res., 112, D23104, doi:10.1029/2007JD008945, 2007.

Gettelman, A., Birner, T., Eyring, V., Akiyoshi, H., Bekki, S., Brühl, C., Dameris, M., Kinnison, D. E., Lefevre, F., Lott, F.,
Mancini, E., Pitari, G., Plummer, D. A., Rozanov, E., Shibata, K., Stenke, A., Struthers, H., and Tian, W.: The Tropical Tropopause Layer 1960-2100, Atmos. Chem. Phys., 9, 1621-1637, 2009, http://www.atmos-chem-phys.net/9/1621/2009/.

Giorgetta, M. A., Manzini, E., Roeckner, E., Esch, M., and Bengtsson, L.: Climatology and Forcing of the Quasi-Biennial Oscillation in the MAECHAM5 Model, J. Climate, 19(6), 3882-3901, 2006.

Hegglin, M. I., Brunner, D., Peter, T., Hoor, P., Fischer, H., Staehelin, J., Krebsbach, M., Schiller, C., Parchatka, U., and Weers, U.: Measurements of $\mathrm{NO}, \mathrm{NO}_{\mathrm{y}}, \mathrm{N}_{2} \mathrm{O}$, and $\mathrm{O}_{3}$ during SPURT: implications for transport and chemistry in the lowermost stratosphere, Atmos. Chem. Phys., 6, 1331-1350, 2006, http://www.atmos-chem-phys.net/6/1331/2006/.

Hegglin, M. I. and Shepherd, T. G.: $\mathrm{O}_{3}-\mathrm{N}_{2} \mathrm{O}$ correlations from the Atmospheric Chemistry Experiment: Revisiting a diagnostic of transport and chemistry in the stratosphere, J. Geophys. Res., 112, D19301, doi:10.1029/2006JD008281, 2007.

Hegglin, M. I., Boone, C. D., Manney, G. L., Shepherd, T. G., Walker, K. A., Bernath, P. F., Daffer, W. H., Hoor, P., and Schiller, C.: Validation of ACE-FTS satellite data in the upper troposphere/lower stratosphere (UTLS) using non-coincident measurements, Atmos. Chem. Phys., 8, 1483-1499, 2008, http://www.atmos-chem-phys.net/8/1483/2008/.

Hegglin, M. I., Boone, C. D., Manney, G. L., and Walker, K. A.: A global view of the extratropical tropopause transition layer from Atmospheric Chemistry Experiment Fourier Transform Spectrometer $\mathrm{O}_{3}, \mathrm{H}_{2} \mathrm{O}$, and CO, J. Geophys. Res., 114, D00B11, doi:10.1029/2008JD009984, 2009.

Heyes, W. J., Vaughan, G., Allen, G., Volz-Thomas, A., Pätz, H.W., and Busen, R.: Composition of the TTL over Darwin: local mixing or long-range transport?, Atmos. Chem. Phys. Discuss., 9, 7299-7332, 2009

Highwood, E. J. and Hoskins, B. J.: The tropical tropopause, Q. J. Roy. Meteorol. Soc., 124(549), 1579-1604, 1998.

Holton, J., Haynes, P., McIntyre, M., Douglass, A., Rood, R., and Pfister L.: Stratosphere-Troposphere Exchange, Rev. Geophys., 33(4), 403-439, 1995.

Hoor, P., Gurk, C., Brunner, D., Hegglin, M. I., Wernli, H., and Fischer, H.: Seasonality and extent of extratropical TST derived from in-situ CO measurements during SPURT, Atmos. Chem. Phys., 4, 1427-1442, 2004, http://www.atmos-chem-phys.net/4/1427/2004/.

Jöckel, P., Sander, R., Kerkweg, A., Tost, H., and Lelieveld, J.: Technical Note: The Modular Earth Submodel System (MESSy) - a new approach towards Earth System Modeling, Atmos. Chem. Phys., 5, 433-444, 2005,

http://www.atmos-chem-phys.net/5/433/2005/.

Jöckel, P., Tost, H., Pozzer, A., Brühl, C., Buchholz, J., Ganzeveld, L., Hoor, P., Kerkweg, A., Lawrence, M. G., Sander, R., Steil, B., Stiller, G., Tanarhte, M., Taraborrelli, D., van Aardenne, J., and Lelieveld, J.: The atmospheric chemistry general circulation model ECHAM5/MESSy 1: consistent simulation of ozone from the surface to the mesosphere, Atmos. Chem. Phys., 6, 50675104, 2006, http://www.atmos-chem-phys.net/6/5067/2006/

Kerkweg, A., Sander, R., Tost, H., and Jöckel, P.: Technical note: Implementation of prescribed (OFFLEM), calculated (ONLEM), and pseudo-emissions (TNUDGE) of chemical species in the Modular Earth Submodel System (MESSy), Atmos. Chem. 
Phys., 6, 3603-3609, 2006,

http://www.atmos-chem-phys.net/6/3603/2006/.

Konopka, P., Günther, G., Müller, R., dos Santos, F. H. S., Schiller, C., Ravegnani, F., Ulanovsky, A., Schlager, H., Volk, C. M., Viciani, S., Pan, L. L., McKenna, D.-S., and Riese, M.: Contribution of mixing to upward transport across the tropical tropopause layer (TTL), Atmos. Chem. Phys., 7, 3285-3308, 2007, http://www.atmos-chem-phys.net/7/3285/2007/.

Kremser, S., Rex, M., Langematz, U., Dameris, M., and Wohltmann, I.: Validation of water vapour transport in the tropical tropopause region in coupled Chemistry Climate Models, Atmos. Chem. Phys., 9, 2679-2694, 2009,

http://www.atmos-chem-phys.net/9/2679/2009/.

Kyrö, E., Kivi, R., Turunen, T., Aulamo, H., Rudakov, V. V., Khattatov, V. V., MacKenzie, A. R., Chipperfield, M. P., Lee, A. M., Stefanutti, L., and Ravegnani, F.: Ozone measurements during the Airborne Polar Experiment: Aircraft instrument validation; isentropic trends; and hemispheric fields prior to the 1997 Arctic ozone depletion, J. Geophys. Res., 105, 14599-14611, 2000.

Lelieveld, J., Brühl, C., Jöckel, P., Steil, B., Crutzen, P. J., Fischer, H., Giorgetta, M. A., Hoor, P., Lawrence, M. G., Sausen, R., and Tost, H.: Stratospheric dryness: model simulations and satellite observations, Atmos. Chem. Phys., 7, 1313-1332, 2007, http://www.atmos-chem-phys.net/7/1313/2007/.

Liu, C., Zipser, E., Garrett, T., Jiang, J. H., and Su, H.: How do the water vapor and carbon monoxide tape recorders start near the tropical tropopause?, Geophys. Res. Lett., 34, L09804, doi:10.1029/2006GL029234, 2007.

Lohmann, U. and Roeckner, E: Design and performance of a new cloud microphysics scheme developed for the ECHAM general circulation model, Clim. Dynam., 12(8), 557-572, 1996.

MacKenzie, A. R., Schiller, C., Peter, T., Adriani, A., Beuermann, J., Bujok, O., Cairo, F., Corti, T., DiDonfrancesco, G., Gensch, I., Kiemle, C., Krämer, M., Kröger, C., Merkulov, S., Oulanovsky, A., Ravegnani, F., Rohs, S., Rudakov, V., Salter, P., Santacesaria, V., Stefanutti, L., Yushkov, V.: Tropopause and hygropause variability over the equatorial Indian Ocean during February and March 1999, J. Geophys. Res., 111, D18112, doi:10.1029/2005JD006639, 2006.

Mote, P., Rosenlof, W. K., Mclntyre, M., Carr, E., Gille, J., Holton, J., Kinnersley, J., Pumphrey, H., Russell III, J. M., and Waters, J.: An atmospheric tape recorder: The imprint of tropical tropopause temperatures on stratospheric water vapor, J. Geophys. Res., 101, 3989-4006, 1996.

Neu, J. L., Sparling, L. C., and Plumb, R. A.: Variability of the subtropical "edges" in the stratosphere, J. Geophys. Res., 108(D15), 4482, doi:10.1029/2002JD002706, 2003.

Pan, L. L., Randel, W. J., Gary, B. L., Mahoney, M. J., and Hintsa, E. J.: Definitions and sharpness of the extratropical tropopause: A trace gas perspective, J. Geophys. Res., 109, D23103, doi:10.1029/2004JD004982, 2004.

Pan, L. L., Wei, J. C., Kinnison, D. E., Garcia, R. R., Wuebbles, D. J., and Brasseur, J. P: A set of diagnostics for evaluating chemistry-climate models in the extratropical tropopause region, J. Geophys. Res., 112, D09316, doi:10.1029/2006JD007792, 2007.

Park, S., Jiménez, R., Daube, B. C., Pfister, L., Conway, T. J., Gottlieb, E. W., Chow, V. Y., Curran, D. J., Matross, D. M., Bright, A., Atlas, E. L., Bui, T. P., Gao, R.-S., Twohy, C. H., and Wofsy,
S. C.: The $\mathrm{CO}_{2}$ tracer clock for the Tropical Tropopause Layer, Atmos. Chem. Phys., 7, 3989-4000, 2007,

http://www.atmos-chem-phys.net/7/3989/2007/.

Plumb, R. A.: Tracer-tracer relationships in the stratosphere, Rev. Geophys., 45, RG4005, doi:10.1029/2005RG000179, 2007.

Prinn, R. G., Weiss, R. F., Fraser, P. J., Simmonds, P. G., Cunnold, D. M., Alyea, F. N., O’Doherty, S., Salameh, P., Miller, B. R., Huang, J., Wang, R. H. J., Hartley, D. E., Harth, C., Steele, L. P., Sturrock, G., Midgley, P. M., and McCulloch, A.: A history of chemically and radiatively important gases in air deduced from ALE/GAGE/AGAGE, J. Geophys. Res., 105(D14), 1775117792, 2000.

Randel, W. J., Wu, F., Gettelman, A., Russell III, J. M., Zawodny, J. M., and Oltmans, S. J.: Seasonal variation of water vapor in the lower stratosphere observed in Halogen Occultation Experiment data, J. Geophys. Res., 106(D13), 14313-14325, 2001.

Randel, W. J., Wu, F., and Forster, P.: The extratropical tropopause inversion layer: global observations with GPS data, and a radiative forcing mechanism. J. Atmos. Sci., 64, 4489-4496, 2007.

Roeckner, E., Bäuml, G., Bonaventura, L., Brokopf, R., Esch, M., Giorgetta, M., Hagemann, S., Kirchner, I., Kornblueh, L., Manzini, E., Rhodin, A., Schlese, U., Schulzweida, U., and Tompkins, A.: The atmospheric general circulation model ECHAM5. PART I: Model description, Max Planck Institute for Meteorology, MPI-Report 349, online available at: http://www.mpimet.mpg.de/fileadmin/models/echam/ mpi_report_349.pdf, 2003.

Roeckner, E., Brokopf, R., Esch, M., Giorgetta, M., Hagemann, S., Kornblueh, S., Manzini, E., Schlese U., and Schulzweida, U.: Sensitivity of Simulated Climate to Horizontal and Vertical Resolution in the ECHAM5 Atmosphere Model, J. Climate, 19(16), 3771-3791, doi:10.1175/JCLI3831.1, 2006.

Russell, P. B., Pfister, L., and Selkirk, H. B.: The Tropical Experiment of the Stratosphere-Troposphere Exchange Project (STEP): Science objectives, operations, and summary findings, J. Geophys. Res., 98, 8563-8590, 1993.

Sherwood, S. C. and Dessler, A. E.: A model for transport across the tropical tropopause, J. Atmos. Sci., 58, 765-779, 2001.

Schoeberl, M. R., Duncan, B. N., Douglass, A. R., Waters, J., Livesey, N., Read, W., and Filipiak, M.: The carbon monoxide tape recorder, Geophys. Res. Lett., 33, L12811, doi:10.1029/2006GL026178, 2006.

Sparling, L. C.: Statistical perspectives on stratospheric transport, Rev. Geophys., 38(3), 417-436, 2000.

Stefanutti, L., Mackenzie, A. R., Santacesaria, V., Adriani, A., Balestri, S., Borrmann, S., Khattov, V., Mazzinghi, P., Mitev, V., Rudakov, V., Schiller, C., Toci, G., Volk, C. M., Yushkov, V., Flentje, H., Kiemle, C., Redaelli, G., Carslaw, K. S., Noon, K., and Peter, Th.: The APE-THESEO Tropical Campaign: An Overview, J. Atmos. Chem., 48(1), 1-33, 2004.

Thompson, A. M. and Witte, J. C.: SHADOZ (Southern Hemisphere Additional Ozonesondes): A new data set for the earth science community, Earth Observer, 11(4), 27-30, 1999.

Thuburn, J. and Craig, G. C.: On the temperature structure of the tropical substratosphere, J. Geophys. Res., 107(D2), 4017, doi:10.1029/2001JD000448, 2002.

Vaughan, G., Schiller, C., MacKenzie, A. R., Bower, K., Peter, T., Schlager, H., Harris N. R. P., and May, P. T.: SCOUTO3/ACTIVE: High-altitude aircraft measurements around deep 
tropical convection, B. Am. Meteorol. Soc., 89(5), 647-662, 2008.

Viciani, S., D’Amato, F., Mazzinghi, P., Castagnoli, F., Toci, G., and Werle, P. A.: Cryogenically operated laser diode spectrometer for airborne measurement of stratospheric trace gases, Appl. Phys. B, 90(3-4), 581-592, 2008.

Volk, C. M., Riediger, O., Strunk, M., Schmidt, U., Ravegnani, F., Ulanovsky, A., and Rudakov, V.: In situ Tracer Measurements in the Tropical Tropopause Region During APE-THESEO, Eur. Comm. Air Pollut. Res., Report 73, 661-664, 2000.

Vömel, H., Oltmans, S. J., Johnson, B. J., Hasebe, F., Shiotani, M., Fujiwara, M., Nishi, N., Agama, M., Cornejo, J., Paredes, F., and Enriquez, H.: Balloon-borne observations of water vapor and ozone in the tropical upper troposphere and lower stratosphere, J. Geophys. Res., 107(D14), 4210, doi:10.1029/2001JD000707, 2002.

Weinstock, E. M., Hintsa, E. J., Dessler, A. E., and Anderson, J. G.: Measurements of water vapor in the tropical lower stratosphere during the CEPEX Campaign: Results and interpretation, Geophys. Res. Lett., 22(23), 3231-3234, 1995.
Witte, J. C., Schoeberl, M. R., Douglass, A. R., and Thompson, A. M.: The Quasi-biennial Oscillation and annual variations in tropical ozone from SHADOZ and HALOE, Atmos. Chem. Phys., 8, 3929-3936, 2008, http://www.atmos-chem-phys.net/8/3929/2008/.

World Meteorological Organisation (WMO): Definition of the tropopause, WMO Bull., 6, p. 136, 1957.

Yushkov V., Oulanovsky, A., Lechenuk, N., Rudakov, I., Arshinov, K., Tikhonov, F., Stefanutti, L., Ravegnani, F., Bonafe, U., and Georgiadis, T.: A chemilumineschent Analyser for stratospheric Measurements of the Ozone Concentration (FOZAN), J. Atmos. Ocean. Tech., 16, 1345-1350, 1999.

Zöger, M., Afchine, A., Eicke, N., Gerhards, M.-T., Klein, E., McKenna, D. S., Mörschel, U., Schmidt, U., Tan, V., Tuitjer, F., Woyke, T., and Schiller, C.: Fast in situ stratospheric hygrometers: A new family of balloon-borne and airborne Lyman $\alpha$ photofragment fluorescence hygrometers, J. Geophys. Res., 104(D1), 1807-1816, doi:10.1029/1998JD100025, 1999. 